\title{
Policing, Punishing and Prisons in the Early Islamic Egyptian Countryside (640-85 O CE)
}

\author{
Petra M. Sijpesteijn
}

The Greek, Coptic and Arabic papyri from early Islamic Egypt contain numerous references to punishments, fines and forced confinement before a systematised Islamic legal system was instituted. But they also document the settlement of legal conflicts through mediation and other informal processes drawing upon existing practices and showing changes after the Arabs' arrival.

Using the papyri this article* will show what patterns in the organisation and practice of legal conflict-resolution - as seen in extra-judicial arbitration, civil litigation and criminal law cases - can be detected in the earliest period of Muslim history in the province. What infrastructure existed and to what extent did this build on instruments and procedures already in place? What was the role of the central authorities in the capital Fusțāt vis-à-vis local actors? How did private initiatives and responsibilities compare to public ones? And how did these instruments help to maintain control in the Egyptian countryside in the first two centuries of Muslim rule?

Papyri $^{1}$

Invaluable for our understanding of so many areas of Egyptian life, papyrus documents are also a uniquely rich source for juridical and legal practice in the

* This work was supported by the European Research Council under Grant number 683194. I would like to thank Marie Legendre, Lucian Reinfandt and Mathieu Tillier for their comments on this article. Any remaining mistakes are, of course, my own.

1 The following abbreviations are used in this article to refer to papyrus editions: $B G U$ III = Ägyptische Urkunden aus den Königlichen Museen zu Berlin, Griechische Urkunden III (Berlin: Königliche Museen zu Berlin, 1903); Chrest.Khoury I = Raif G. Khoury, ed., Chrestomathie de papyrologie arabe (Leiden: Brill, 1993); CPR IV = Walter Till, ed., Corpus Papyrorum Raineri IV: die koptischen Rechtsurkunden der Papyrussammlung der Oesterreichischen Nationalbibliothek (Vienna: Adolf Holzhausens Nachfolger, 1958); CPR XVI = Werner Diem, ed., Corpus Papyrorum Raineri XVI: Arabische Briefe aus dem 7. bis 10. Jahrhundert (Vienna: Brüder Hollinek, 
Egyptian countryside in the first centuries of Muslim rule. The Muslims used papyrus as their main day-to-day writing material throughout this period, shifting to paper only in the ninth-tenth century CE. Most Egyptian papyri are

1993); $C P R$ XXII = Federico Morelli, ed., Corpus Papyrorum Raineri XXII: Griechische Texte XV, Documenti greci per la fiscalità e la ammini-strazione dell'Egitto arabo (Vienna: Brüder Hollinek, 2001); CPR XXIV = Bernhard Palme, ed., Corpus Papyrorum Raineri XXIV: Griechische Texte XVII, Dokumente zu Verwaltung und Militär aus dem spätantiken Ägypten (Vienna: Brüder Hollinek, 2002); CPR XXVI = Michael E. Thung, ed., Corpus Papyrorum Raineri XXVI: Arabische juristische Urkunden aus der Papyrussammlung der Österreichischen Nationalbibliothek (Munich-Leipzig: De Gruyter, 2006); CPR Xxx = Federico Morelli, ed., Corpus Papyrorum Raineri XXX: L'archivio di Senouthios anystes e testi connessi (Berlin/New York: De Gruyter, 2010); O.Crum vc = Walter C. Crum ed., Varia Coptica (Aberdeen: University Press, 1939); O.Frangé = Anne Boud'hors and Chantal Heurtel, eds., Les ostraca coptes de la TT29: autour du moine Frangé (Études de l'archéologie thébaine 3) (Brussels: CReA-patrimoine, 2010); P.Ant. III = John W.B. Barns and Henrik Zilliacus, eds., The Antinoopolis Papyri (London: Egypt Exploration Society, 1967); P.Apoll. = Roger Rémondon, ed., Papyrus grecs d'Appollônos Anô, Documents de fouilles de l' Institut Français d' Archéologie Orientale du Caire 19 (Cairo: Imprimerie de l' Institut français d' archéologie orientaae, 1953); P.Berl.Arab. II = Werner Diem, ed., Arabische Briefe des 7. bis 13. Jahrhunderts aus den Staatlichen Museen Berlin, Documenta Arabica Antiqua 4 (Wiesbaden: Harrasowitz, 1997); P.Cair.Arab. = Adolf Grohmann, ed., Arabic Papyri in the Egyptian Library (Cairo: Egyptian Library Press, 1934-1962); PERF = Joseph von Karabacek, Papyrus Erzherzog Rainer: Führer durch die Ausstellung (Vienna: A. Hölder, 1894); P.Hamb.Arab. II = Albert Dietrich, ed., Arabische Papyri aus der Hamburger Staatsund Universitäts-Bibliothek (Hamburg: J.J. Augustin, 1955); P.Heid.Arab. I = Carl H. Becker, ed., Papyri Schott-Reinhardt I (Heidelberg: Carl Winter, 19o6); P.Horak = Hermann Harrauer and Rosario Pintaudi, eds., Gedenkschrift Ulrike Horak, Papyrologica Florentina XxxIV (Firenze: Gonnelli, 2004); P.Khalili I = Geoffrey Khan, ed., Arabic Papyri: Selected Material from the Khalili Collection (New York/London/Oxford: Nour Foundation in association with Azimuth Editions and Oxford University Press, 1992); P.Kölnägypt. II = Gesa Schenke, ed., Kölner ägyptische Papyri II Koptische Urkunden der früharabischen Zeit, Papyrological Coloniensia IX/2 (Paderborn: Ferdinand Schöningh, 2016); P.KRU = Walter E. Crum, ed., Koptische Rechtsurkunden des achten Jahrhunderts aus Djême (Theben) (Leipzig: J.C. Hinrichs, 1912); P.Lond. IV = Harold I. Bell, ed., Greek Papyri in the British Museum (London: British Museum, 1910); P.Marchands = Yūsuf Rāgib, ed., Marchands d'étoffes du Fayyoum au IIIe/IXe siècle d'après leurs archives (actes et lettres) (Cairo: Institut français d' archéologie orientale, 1996); P.Mird = Adolf Grohmann, ed., Arabic Papyri from Khirbet el-Mird (Louvain: Publications Universitaires, 1963); P.Mon.Epiph. = Walter E. Crum and Hugh G. Evelyn-White, eds., The Monastery of Epiphanius at Thebes, part II (New York: Metropolitan Museum of Art, 1926); P.Oxy = The Oxyrhynchus Papyri (London: Egypt Exploration Society in Graeco-Roman Memoirs); P.Prag.Arab. $=$ Adolf Grohmann, ed., "Arabische Papyri aus der Sammlung Carl Wessely im orientalischen Institute (Orientální Ústav) zu Prag," Archiv Orientální 10 (1938): 149-162; 11 (1939): 242-289; 12 (1941): 1-112; 14 (1943): 161-26o; P.Qurra = Nabia Abbott, ed., The Kurrah Papyri from Aphrodito in the Oriental Institute, Studies in Ancient Oriental Civilization 15 (Chicago: University of Chicago Press, 1938); P.Ryl.Arab. I = David S. Margoliouth, ed., Catalogue of Arabic Papyri in the John Rylands Library Manchester (Manchester: Manchester University Press, 1933); P.Scholl = Georg Schmelz, ed., "Zwei koptische Schutzbriefe aus der 
found outside the main centres of occupation and government, in the uninhabitable desert areas that make up most of the country's land mass, where, free from rain disturbance, they lay protected since being discarded some fifteen hundred years ago.

Never intended to be preserved, the papyri offer uniquely direct access to the society that produced them. But the often haphazard circumstances of their discovery and conservation also offer formidable challenges. Most were unearthed during ad hoc, amateur or even illegal excavations, with no provenance, place of origin or date. Sometimes the date is given at the end of the text. More commonly, however, it has to be inferred on the basis of palaeographical criteria and the formulae used - a rough method that divides the papyri into large groups spanning more than a century. Where the find site is not known, provenance can similarly sometimes be reconstructed from internal evidence. Because archaeological activity on mediaeval sites in Egypt was often not systematic, let alone exhaustive, the chronological and geographic distribution of papyri is uneven, with some areas over represented and others hardly featuring at all. Obviously, papyri can also tell us about places other than where they were found through the references or allusions made in them. In this paper the date and provenance of papyri are given when known, but in the discussion that follows they have been treated as one source body. While this might obscure specific historical and geographical patterns, it offers enough detail to observe some long-term historical processes and developments.

With many of the papyri lacking a clear context, a small number of especially rich and well-studied dossiers of related texts have dominated the field. These papyri have been successfully used to reconstruct administrative and fiscal practices under the early Muslims in Egypt. The challenge still remains though to combine the dossiers which stem from different periods, areas and levels in the administration, while also incorporating relevant stand-alone papyri, into one integrated historical picture. ${ }^{2}$ An additional task is to bring the material

Heidelberger Papyrussammlung," in Von Sklaven, Pächtern und Politikern, eds. Lutz Popko, Nadine Quenoille and Michaela Rücker (Berlin: De Gruyter, 2012), 222-229; $S B$ = Sammelbuch griechischer Urkunden aus Aegypten, 1915-; SPP = Carl Wessely, ed., Studien zur Palaeographie und Papyruskunde (Leipzig: Avenarius, 1901-1924).

2 See especially (in chronological order): the Greek letters of Senouthios, (ca. 634) (CPR Xxx) who was administrator in the Hermopolite (Ashmūnayn). The Greek documents related to the pagarch Papas of Idfū (649-688) texts are published in P.Apoll. The (unpublished) Coptic material is discussed in Leslie MacCoull, "The Coptic Papyri from Apollonos Ano," in Proceedings of the XVIIIth International Congress of Papyrology, ed. Basil G. Mandilaras (Athens: Greek Papyrological Society, 1988), 141-16o. For the dates of these texts, see Jean Gascou and Klaas A. Worp, "Problèmes de documentation apollinopolite," Zeitschrift für Papyrologie und 
from administrative contexts in contact with documents related to the private sphere. Only then can the papyri be brought to bear on larger historical questions, moving from detailed information about local day-to-day activities to developments and processes taking place on a higher plane: from the micro to the macro.

A final consideration in terms of our evidence is the linguistic situation. Starting directly after their arrival, the Muslim conquerors used Arabic in parallel with Egypt's other two languages, Coptic and Greek, to communicate with the province's inhabitants. After the conquest Coptic was used for the first time in the Egyptian chancery as an official administrative language. The Arabic documentation from the first half century of Muslim rule in Egypt is, however, much less voluminous than the Greek and Coptic material, and is mostly limited to administrative communications. Coptic and Greek continued to be used for private written communication outside the administration as well. With very few Arabs having settled in the Egyptian countryside, it is indeed in the Coptic and Greek material that most events relating to the non-administrative activities of the Egyptian population would have been recorded under the first two centuries of Muslim rule. Due to the general lack of explicit dates on nonofficial documents, however, most Coptic and Greek papyri that have been assigned a firm date in the Arab period originated in the chancery and its regional offices. Few 'private' documents have been dated to the Arab period. In general, moreover, the Greek material has received much more attention than has the Coptic or Arabic.

Epigraphik 49 (1982): 83-95. Cf. Clive Foss, "Egypt under Mu'āwiya, part I: Flavius Papas and Upper Egypt," Bulletin of the School for Oriental and African Studies 72 (2009):1-24. For the Arabic, Coptic and Greek documentation of the pagarchy of Aphroditō/Ishqūh and its pagarch Basileios, see the list of published papyri in Tonio Sebastian Richter, "Language Choice in the Qurra Dossier," in The Multilingual Experience in Egypt: from the Ptolemies to the Abbāsids, ed. Arietta Papaconstantinou (Burlington: Ashgate Publishing, 2010), 189-220. Some Arabic material has been published since, see Petra M. Sijpesteijn, "Une nouvelle lettre de Qurra b. Šarīk. P.Sorb. inv. 2345," Annales Islamologiques 45 (2011): 257-267; and Naim Vantieghem, "La correspondance de Qurra b. Šarīk et de Basileios revisitée. I. À propos d' une lettre récemment publiée," Chronique d'Egypte 91 (2016): 204-210. For the Arabic and Greek papyri related to Nājid ibn Muslim, pagarch of the Fayyūm ca. 730 and his subordinate 'Abd Allāh ibn As'ad, who governed the southwestern part of the Fayyūm oasis, see Petra M. Sijpesteijn, Shaping a Muslim State: The World of a Mid-Eighth-Century Egyptian Official (Oxford: Oxford University Press, 2013). Private dossiers from this period are limited to the Coptic ostraca related to the monk Frangé operating in Thebes in the first half of the eighth century (Anne Boud'hors and Chantal Heurtel, Les ostraca coptes de la TT29: autour du moine Frangé. Études de l'archéologie thébaine 3 (Brussels: CReA-patrimoine, 2010)) and the Arabic papyri of the Banū 'Abd al-Mu'min, a ninth-century textile merchant's family (P.Marchands). 
The references to legal conflicts and the practicalities of settlement, punishment and incarceration occur in different genres of texts. Official letters discuss conflicts between private individuals brought before the central authorities in order to be resolved by government representatives. Other administrative writings give orders on how to deal with those deemed to have undermined the government's activities, mainly tax collection, or to have disturbed the public order. Petitions and informal requests to office-holders or those otherwise endowed with authority report on disputes, but also provide information on the background and circumstances of prisoners and those being punished. Other letters also occasionally relay episodes involving the law, prisons or other punishments pertaining to the letter-writers themselves or others connected to them. Lists of prisoners, sometimes including information on the crimes they have committed, or other accounts and lists relating to prison life are another source. Finally, the courts and the judge's administration produced documents related to court proceedings and legal decisions. ${ }^{3}$

\section{Administrative Law: Fact-Finding and Procedure}

The papyri show legal procedure in action. In official letters in response to complaints or petitions brought before government officials, dating from the late seventh century onwards, lower-placed officials are ordered to "look into" the matter and "find evidence" (aqāma 'alā dhālika al-bayyina) for the case raised by the plaintiff. ${ }^{4}$ On the other side, the accused offers his point of view, which is judged by the official in charge. This can be observed in a ninth-century letter in which someone defends himself against a charge of having stolen alfa (halfä). The accused denies having stolen anything and challenges the plaintiff to produce evidence proving otherwise: "if he presents to you evidence and it is verified in his favour that we have taken the alfa, then we will give it to him.

3 See Lucian Reinfandt, "Law and Order in der frühen islamischen Gesellschaft? Strafverfolgung in Ägypten und Palästina nach der arabischen Eroberung (7.-9. Jahrhundert)," in Interkulturalität in der Alten Welt: Vorderasien, Hellas, Ägypten und die vielfältigen Ebenen des Kontakts, eds. Robert Rollinger et al. (Wiesbaden: Harrassowitz Verlag, 2010), 655-683, for an overview of Arabic papyri related to crimes, criminals and their punishments.

4 An early example is Werner Diem, "Der Gouverneur an den Pagarchen: ein verkannter Papyrus vom Jahre 65 der Hiğra," Der Islam 6o (1983): 104-111, dated 65/684, provenance alUshmūnayn. A group of letters written by Qurra b. Sharīk date to the early eighth century (P.Heid.Arab. I 10; P.Heid.Arab. I 11; P.Qurra 3; P.Cair.Arab. III 154; P.Cair.Arab. III 155; Carl H. Becker, "Arabische Papyri des Aphroditofundes," Der Islam 2 (1911): 245-268, no. 1; provenance of all is Ishqūh). 
If (on the other hand) this is not confirmed with you, then handle according to what is right" (in aqūma indaka al-bayyina wa-șahha lahu annā akhadnā halfă' dafa'nā ilayhiwa-in lamyașiḥh dhālika indaka 'amilta fi dhālika bimā wāfaqa alhaqq). ${ }^{5}$ Uniquely, this case can be traced further in a follow-up letter from the person in charge. Having read the accusation and denial, the official, one Abū al-Qāsim, who presumably held some position of authority, orders the plaintiff and accused to appear before him so that they can both present their claim and he can decide to whom the alfa belongs. ${ }^{6}$ Similarly, in another ninth-century letter from the Fayyūm, the sender asks the addressee, the responsible person (wakil) in Babijj, to restore to a third person his rights vis-à-vis his opponent and not to allow him to be oppressed and opposed (lä tarkhus fi zulmihi wamudāf'atihi). If, however, the case is not clear to the addressee, he should have both parties come to the sender so that he can himself look into the matter. ${ }^{7}$ Finally, a ninth-century witness declaration records the procedure of proof and oath-taking in a dispute between two brothers over a delivery of four pieces of cloth. ${ }^{8}$

These examinations into evidence could be extensive. An example of the discovery process extending far into the past and involving archival research comes from a letter dated 9o/709 in which the governor Qurra b. Sharik (in office 709-715) asks Basileios, the pagarch of Ishqūh, to find out whether the claim of some (Arab) soldiers concerning their 40-year-long residence in certain villages can be corroborated by documentary evidence preserved in those villages. ${ }^{9}$ Some years later, the governor 'Abd al-Malik b. Yazīd (in office $75^{-}$

5 P.Hamb.Arab. II 3, provenance Idfū.

6 "I have read your letter and understood what you mentioned concerning the case of the man who took the alfa. Surely he has to come to Idfū before Abū al-Qāsim and they (plaintiff and accused) can then present their case to each other and I will see to whom the alfa belongs" (qad qara'tu kitābaka wa-fahimtu mā dhakarta fihi min amr al-rajul alladhī hamala al-ḩalfä wa-lā budd lahu min ishḥạșihi ilā idfū quddām abū al-qāsim wa-yatanāṣarū wa-abșaru li-man șāra lahu al-ḥalfä’) P.Hamb.Arab. II 4, provenance Idfū.

7 "If their case is obscure to you, then have both come to me so that I can take care of looking into their case" ( fa-in shakala 'alayka amruhumā fa-shkhașhumā ilā mā qibalì li-atawallā alnazr fi amrihimā) Chrest.Khoury I 84, provenance uncertain, probably al-Fayyūm. Cf. Lucian Reinfandt, "Local Judicial Authorities in Umayyad Egypt (41-132/661-750)," Bulletin d'études orientales 63 (2014): 136.

8 P.Marchands I 10, provenance al-Fayyūm.

9 P.Cair.Arab. III 15o. Mathieu Tillier discusses further examples in the correspondence between the governor Qurra and the pagarch Basileios (Mathieu Tillier, "Dispensing Justice in a Minority Context:The Judicial Administration of Upper Egypt under Muslim Rule in the Early Eighth Century," in The Late Antique World of Early Islam: Muslims among Jews and Christians in the East Mediterranean, ed. Robert Hoyland (Princeton: Darwin Press, 2015), 133-156; idem, 
754) writes to Khuzayma b. Māhān, head of an administrative district, that he had sent him an aide to examine the complaint raised by the inhabitants of his district against a certain 'Abd al-Wāhiid b. Qays. Khuzayma and his companion are ordered to look carefully into the complaint and to report in writing to the governor. ${ }^{10}$ The involvement of the governor and the dispatch of extra personnel from the capital to deal with this matter indicates its seriousness, or perhaps the status of the parties involved.

Several documents, however, some also originating in an administrative context, suggest that fact-finding was not always taken so seriously. The sender of a ninth-century letter simply asks the addressee to beat up a boy accused of stealing straw from his stables and frighten him with physical mistreatment into returning the goods he has taken. On the other hand, the accused's status as a manumitted slave might have lowered his chances of being treated fairly. ${ }^{11}$ In another case the governor Qurra b. Sharīk orders the pagarch Basileios to use force against the accused, who is said illegally to have occupied the house of the claimant. ${ }^{12}$ Of course, it is not clear from these letters whether the addressees indeed proceeded without a proper investigation.

Such cases also show how oral and written reports relating to legal cases travelled through different offices, while the claimants themselves could also be heard at different administrative levels. Cases could move up and down the administrative hierarchy as responsibility was transferred as part of a formal process, or when conflicting interests motivated a party to skip or turn to another layer in the administration. In some instances evidence about a specific complaint was gathered and examined at the order of higher officials. Occasionally, if a lower official could establish that the plaintiff was in the right, he was left free to deal with the case. For example, in response to an accusation of stealing or taking unlawful possession of an amount of money, the governor Qurra b. Sharik orders the pagarch Basileios to bring the claimant and defendant together to decide who is right and to inflict the appropriate punishment on the guilty party. ${ }^{13}$ Restitution of the plaintiff's rights usually involved nothing more than restoring his property. If, however, the plaintiff's

"Du pagarque au cadi: Ruptures et continuités dans l' administration judiciaire de la hauteÉgypte (Irer-IIIe/vire-IXe siècle),"Médiévales 64(2013):19-36). See also Lucian Reinfandt's description of the importance of archival and documentary evidence in cases of arbitration (Reinfandt, "Judicial Authorities," 142).

Yūsuf Rāgib, "Lettres Arabes (I)," Annales Islamologiques 14 (1978): 15-35, no. 1, provenance Medīnat al-Fāris, al-Fayyūm.

11 Chrest.Khoury I 80, third/ninth century, provenance unknown.

12 Tillier, "Dispensing Justice," 147, n. 54.

13 P.Heid.Arab. I 10, provenance Ishqūh. Cf. Tillier "Dispensing Justice," 138-142. 
claim could not be corroborated or the case was unclear, someone higher in the administrative hierarchy became involved, calling in both parties to hear them together. ${ }^{14}$ For example, in the letter dated $65 / 684$ in response to a complaint raised by a woman, the recipient is asked to see whether the woman can provide evidence for her claim. If she can, the addressee is to restore her rights. If she cannot, he is to write to the sender, presumably so that he can deal with it himself. ${ }^{15} \mathrm{~A}$ seventh-century letter accompanying a petition from some tax collectors about indigenous Egyptians (anbāt ) who refuse to pay their taxes is sent by the recipient of the petition to someone lower in the administration who will deal with the matter. ${ }^{16} \mathrm{~A}$ higher official could also directly demand the presence of the parties involved in a conflict without involving lower-level administrators, or because a lower official had failed to resolve the issue. An example of this is the pagarch Najid b. Muslim (in office ca. 730) in the Fayyūm calling in "David's two sons" against whom a case was raised, asking a lower official to send them on directly rather than look into the case himself as happens in some of the cases mentioned above. ${ }^{17}$ Similarly, several documents demand that (suspected) culprits be presented to the official in charge of their case. In the seventh and eighth centuries such orders, in Coptic and Greek, were issued in the name of heads of monasteries and other local authorities. An example of this can be found in the list of men sought concerning diverse claims and cases in sixth/seventh-century Anșinna, whom the count (Gr. komēs) Kallinikos is asked to bring forward from "his villages."18 From the eighth century onwards and into the ninth Arabic versions of such orders were issued by and to Arab-Muslim government officials: pagarchs, governors, and other administrative functionaries. ${ }^{19} \mathrm{In}$ a ninth-century Arabic note an administrator

\footnotetext{
14 See also above, nn. 7 and 8.

15 Diem, "Gouverneur." Similarly, the cases that the governor Qurra b. Sharik asks his pagarch Basileios to handle, some of which are discussed above. The judicial procedure is discussed in detail by Tillier, "Dispensing Justice."

16 P.Berl.Arab. II 23, provenance unknown. See also the seventh-century letter from Khirbet al-Mird, Palestine, in which a lower official intends to implement the verdict of a higher official. He is faced with the refusal of one of the parties to abide by the verdict and is forced to return both parties to the higher official (P.Mird 18). Cf. Reinfandt, "Judicial Authorities," 139.

17 Sijpesteijn, Shaping a Muslim State, no. 21, provenance al-Fayyūm.

18 P.Ant. III 189. I would like to thank Marie Legendre for bringing this text to my attention. The editors write explicitly that "it is not to be regarded as a warrant of arrest to the police authorities."

19 From the eighth century: Sijpesteijn, Shaping a Muslim State, no. 21, provenance al-Fayyūm and Mathieu Tillier, "Deux papyrus judiciaires de Fusțāt (iie/viiie siècle)," Chronique d'Egypte 89 (2014): 412-445, no. 1, provenance probably Fusțāț; from the ninth century:
} 
writes to his subordinate to order some other officials (Ar. 'ummāl) to produce a certain Biqțur, the miller. ${ }^{20}$ Only from the tenth century onwards are such kinds of orders issued by Islamic law court officials. ${ }^{21}$ It is not clear on whom the burden of proof lies in these cases, but both sides evidently had an opportunity to state their case. In a late eighth-century case the defendant-husband is summoned to appear before the qā dì in Fusțāt to answer the claim of the plaintiff, his wife. ${ }^{22}$ It seems that the higher official's decision could then be communicated back to the lower administrative level, presumably because that is where execution of the verdict took place.

The tasks of the administrators in these cases is expressed in terms of "judging" and "restoring rights." A legal procedure is suggested by the expressions "judge in the conflict between him and me" (yaqdi bayni wa-baynahu) and "bring them together (to find out what happened and judge between them)" (ajma baynahu wa-bayna șăhibihi). ${ }^{23}$ The claim to be "doing justice" (anșaf; 'amalta bi-mā wäfiqa al-haqq) and "restoring someone's rights" (an tastakhrija lahum haqqahum, wa-mā kāna min haqq fa-sthakhrijhu) appear as well. ${ }^{24}$ Administrators are also instructed to prevent injustice and oppression to take place. In the just cited example dating to 710 , the pagarch Basileios

P.Ryl.Arab. I I 13 provenance al-Ashmūnayn; PERF 699, provenance unknown, which contains a seal at the bottom. In the pre-Islamic period such warrants were issued by and to government officials (James G. Keenan, Joe G. Manning and Uri Yiftach-Firanko, eds., Law and Legal Practice in Egypt from Alexander to the Arab Conquest (Cambridge: Cambridge University Press, 2014), 506-508).

20 P.Ryl.Arab. I I 13, ninth century, provenance Anșina.

21 Chrest.Khoury I 78, ninth-tenth century; Chrest.Khoury I 79, tenth century, provenance of both is al-Ashmūnayn (also cited in Tillier, "Pagarque," 32). Tillier ("Deux papyrus," 8) cites more tenth-century examples.

22 Tillier, "Deux papyrus," no. 1.

23 The first expression appears in a letter concerning a certain Sa'īd, amìr of Alexandria who is asked to intervene in a case between two men over an imprisoned female slave (Jean David-Weill et al., "Papyrus arabes du Louvre II I," Journal of the Economic and Social History of the Orient 21 (1978): 146-164, no. 25, eighth century, provenance unknown). The second expression can be found P.Heid.Arab. I 10, dated 91/710, provenance Ishqūh, a letter from the governor Qurra b. Sharik. It is also attested in the description of a mediation in a disagreement between a husband and wife over the wife's property (innījama'tu baynahumā) (P.Mird. 18, seventh century, provenance Khirbet al-Mird).

24 anșaf: Chrest.Khoury I 84, provenance unknown, probably al-Fayyūm; 'amalta bi-mā wäfiqa al-haqq P.Hamb.Arab. II 3, provenance Idfū, both dating to the ninth century; wamā kāna min haqaq fa-sthakhrijhu wa-lā tazlimanna 'abdaka P.Heid.Arab. I 10, dated 91/710; provenance Ishqūh; an tastakhrija lahum haqqahum P.Berl.Arab. II 23, seventh century; provenance unknown; wa-mā kāna min haqq fa-sthakhrijhu wa-lā tazlimanna 'abdaka P.Cair.Arab. III 154, dating to 9o-91/709-710, provenance Ishqūh. 
is instructed to "bring the plaintiff and accused together, restore the plaintiff's rights if those are established and make sure that your subjects are not oppressed" (ajma baynahu wa-bayna șāḥibihi wa-mā kāna min ḥaqq fasthakhrijhu wa-lā tazlimanna 'abdaka). Almost half a century later the then governor of Egypt, 'Abd Allāh b. Yazīd (in office 133-136/750-754) instructs the recipient to look into a claim of maltreatment brought to his attention, restore the plaintiff his rights if what he claims is true and not to let any maltreatment occur to his subjects ( fa-unzur fimā dhakara ... fa-istakhrij lahu haqqahu minhu ... wa-là tuqarrir mazlimat). ${ }^{25}$ Let us now turn to the kind of cases that are attested in the papyri, the kinds of punishments that were applied, and by whom.

\section{Crimes and Punishments}

The judicial net in the early Islamic countryside was cast widely, and covered both men and women, of high and low status. ${ }^{26} \mathrm{~A}$ variety of punishments were used, including imprisonment, from which no one was automatically immune.

Fluctuation in the documentary record has been connected to periods of social-political unrest, leading the state to increase its control of people's movements. ${ }^{27}$ Developments towards greater centralisation of state processes similarly led to an expanded state presence and increased penetration by government institutions, with greater supervision giving rise to a correspondingly wider range of possible offences. ${ }^{28}$ Such periods witnessed more examples of punishment, fines and incarceration.

25 Werner Diem, "Drei amtliche Schreiben aus frühislamischer Zeit (Papyrus Erzherzog Rainer, Wien)," Jerusalem Studies in Arabic and Islam 12 (1989): no. 1.

26 For the imprisonment of slaves, see the example of a female slave about whom two parties have a disagreement and which was kept (incarcerated?) by a third person (David-Weill et al., "Papyrus arabes" no. 25, eighth century). According to Islamic law slaves were liable for crimes committed, although their owner was responsible in some cases of criminal justice. Cf. the discussion on class justice and slaves in prison in the Roman, Byzantine and Late Antique world in Jens-Uwe Krause, Gefängnisse im Römischen Reich (Stuttgart: Franz Steiner Verlag, 1996), 137-151, 203-212.

27 Delattre (in this volume) discusses how safe conducts issued to check very localised movement in Upper Egypt might be connected to a period of unrest. The large number of makeshift prisons prepared out of dwellings and other buildings during the conquest must have been motivated by an increased need to detain individuals, including prisoners of war (Sean W. Anthony, "The Domestic Origins of Imprisonment: An Inquiry into an Early Islamic Institution," Journal of the American Oriental Society 129 (2009): 572-573).

28 See the more frequent references to fugitives as a result of an increase in the supervision, 
The most frequently attested instruments for maintaining control through punishment and deterrent were fines and physical constraint. Prisons played a major role in both instances, and they are frequently attested in the papyri. ${ }^{29}$ References to physical abuse as punishment, on the other hand, are extremely rare in the papyri, with crucifixion, flogging and the shaving of hair and beards attested in only a handful of texts. ${ }^{30}$ Fines, on the other hand, are very frequently mentioned (see below).

As in other pre-modern societies, imprisonment rarely functioned as a punishment per se, but rather to hold people waiting to be tried, or as a means to compel (or others on their behalf) the payment of monies owed either as a result of conviction or other entanglements. ${ }^{31}$ Detaining family members was also used to apply pressure on felons who had absconded or who were oth-

recording and interference with people's movements at the end of the seventh beginning of the eighth century (Sijpesteijn, Shaping a Muslim State, 100-102).

29 Legal and literary sources pay much less attention to punitive imprisonment than to physical punishments, public parading and the like. Cf. Irene Schneider, "Imprisonment in Pre-Classical and Classical Islamic Law," Islamic Law and Society 2 (1995): 166.

30 Crucifixion: P.Ryl.Arab. I I 14, eighth century, provenance unknown; flogging P.Lond. IV 1384; P.Heid.Arab I 3, both dated 709, provenance of both is Ishqūh; shaving hair and beard: Sijpesteijn, Shaping a Muslim State, no. 31, dating to the first half of the eighth century, provenance is al-Fayyūm; P.Heid.Arab I 3 dated 9o/7o9, provenance Ishqūh. Cf. Petra M. Sijpesteijn, "Shaving Hair and Beards in Early Islamic Egypt: Muslim Innovation or Universal Punishment?" al-Masāq:Journal of the Medieval Mediterranean 30, no. 1 (2018): 9-25. Cf. Reinfandt, "Law and Order;" idem, "Crime and Punishment in Early Islamic Egypt (642-969)," in Proceedings of the Twenty-Fifth International Congress of Papyrology, Ann Arbor 2007, ed. Traianos Gagos, American Studies in Papyrology (Ann Arbor: University of Michigan Press, 2010), 633-640. For literary references to crucifixion, see Sean W. Anthony, Crucifixion and Death as Spectacle: Umayyad Crucifixion in Its Late Antique Context (New Haven, Ст: American Oriental Society, 2014).

31 In the Muslim world, imprisonment as punishment occurred occasionally especially in the context of ta'zir (Schneider, "Imprisonment," 161-165; idem "Sidjn," in Encyclopaedia of Islam, 2nd ed., vol. 9 (Leiden: Brill, 1997), 9:547-548; Nejmeddine Hentati, "La Prison en Occident musulman médiéval," Arabica 54 (2007): 151-152; Rebecca Gould, "Prisons before Modernity: Incarceration in the Medieval Indo-Mediterranean," al-Masāq: Islam and the Medieval Mediterranean 24 (2012): 181-182). Cf. Frantz Rosenthal, The Muslim Concept of Freedom (Leiden: Brill, 196o). In mediaeval Malikite legal treatises imprisonment is discussed as a form of correction $\left(t a^{\prime} d \bar{i} b\right)$, repression $(a j r)$ and to result in repentance (tawba) (Hentati, "Prison," 153-154), but long-term incarceration is considered not to be part of the system of Islamic penal law (Rudolph Peters, Crime and Punishment in Islamic Law: Theory and Practice from the Sixteenth to the Twenty-First Century, Themes in Islamic Law 2 (Cambridge: Cambridge University Press, 2005), 34). In Italy punitive incarceration was used not before the thirteenth century (Guy Geltner, The Medieval Prison: A Social History (Princeton: Princeton University Press, 2008)). In the Roman and Byzantine empires imprisonment was similarly only rarely used as a punishment per se (Krause, Gefängnisse, $64-91)$. 
erwise absent. Thus the ninth-century writer of a short note in Arabic orders Biqțur the miller from Anșina, his family or his father and son, to report for detention. ${ }^{32}$ In another late ninth-century letter the sender relates that his father was imprisoned on account of a dinar owed to a tax-collector. Once the father was released, presumably on the promise of the debt being paid, the sender refused to pay anything at all! ${ }^{33}$

One of the most common causes for incarceration was the non-payment of debts or fines. ${ }^{34}$ The purpose of imprisonment in this instance was to force the prisoner to pay the money he owed, either from his own assets or through the help of a third party. In a seventh-century Coptic letter a group of prisoners asks the addressee to come urgently to the gaol with money - or else "there will be no life left in us" - presumably to pay off the outstanding debt that had led to them being imprisoned. ${ }^{35}$ In another eighth-century Coptic letter the writer asks the addressee to pray for the release of a certain Azarias who has been taken hostage (Gr. homeros), probably because of unpaid debts. ${ }^{36}$ Another seventh-century case describes how the abbot Pdjege was arrested by a diokêtēs because the money he owed was not guaranteed in time (or correctly). The sender urges the addressee to pay the outstanding debt so that Pdjege can be released. ${ }^{37}$ The sender of an eighth-century Arabic letter writes that he was unexpectedly fined and arrested (asa'äni fi al-ghurm wa-l-sijn) when entering a village. He was released when, as he writes, "I sold everything which I and my family own," apparently to pay a financial claim, a fine or debt. ${ }^{38}$ Similarly, a ninth-century letter describes how a certain Ishāa b. Barī', 'Īsā b. Yahyā and Yahyā, the oil merchant, were incarcerated because no guarantee was given on their behalf for the harvest they had to produce on the land for which they were responsible. The addressee's letter - possibly containing such a guarantee - was supposed to make a difference in their case. ${ }^{39}$ Finally, an order to release a certain Yuhannis b. Kināna states that Abū Rāzī stands guarantor for Yuhannis and agrees to pay his debt when Yuhannis is set free. ${ }^{40}$ Some of the Coptic "letters of protection" asserting the recipient's right "to return home" can certainly be

32 P.Ryl.Arab. I I 13.

33 P.Hamb.Arab. II 17, provenance Armant.

34 This is also the form of imprisonment that Muslim jurists pay most attention to (Schneider, "Imprisonment," 169).

35 P.Mon.Epiph. 177, provenance Jēme.

36 O.Frangé 632, provenance Thebes.

37 P.Köln̈̈gypt. II 44, provenance unknown.

$3^{8} \quad$ P.Khalili $\mathrm{I}$ 14, provenance not mentioned.

$39 \quad C P R$ XVI 11, provenance not mentioned.

40 P.Ryl.Arab. I I 15 = Chrest.Khoury I 85, ninth century, provenance al-Ashmūnayn. 
interpreted as allowing prisoners to be released after their fine, taxes, or other debts had been paid or guaranteed for. In one case, the guarantor and sender of the letter promises to make sure no one will arrest the recipient of the letter. The sender of the protection letter thus stood guarantor for or paid the money the recipient owed..$^{41}$ Some of the protection letters state that the protector and sender of the letter will not detain or confine the recipient, presumably because the debt has been guaranteed or paid off. ${ }^{42}$ Proof of lack of funds, on the other hand, could be used as grounds for releasing a prisoner. ${ }^{43}$ The emphasis by certain prisoners on their 'poverty' might be a reference to this. ${ }^{44}$ In a ninthcentury letter the sender pleads that his fiscal debt be removed stating "if I will be incarcerated, I will starve to death." 45

Non-payment of taxes could lead to imprisonment by the authorities. At the beginning of the eighth century certain inhabitants of the Upper Egyptian town of Ishqūh were incarcerated because they had failed to pay their jizya. ${ }^{46}$ During Qurra b. Sharik's governorship, pagarchs also took to imprisoning taxpayers who were behind in their jizya. ${ }^{47}$ That the Arab system of strict fiscal documentation and the more comprehensive tax collection - and heavier tax burden - it allowed did indeed weigh heavily on the Egyptians can be inferred from an eighth-century list of prisoners and their crimes. Four men were in prison because they had burnt a tax role, presumably in an attempt to sabotage the imposition of tax payments. ${ }^{48}$ The ninth-century writer who was pressured by a tax-collector to pay a dinar and faced his father's imprisonment as a pressure measure to pay up has been discussed already above. ${ }^{49}$ Even well-to-do inhabitants were held for non-payment to the fisc, such as a certain Abū al-Faḍl in the ninth century, who was only able to be released after he had paid $35^{\circ}$

$41 \quad$ P.Vind.Copt. 184. I would like to thank Eline Scheerlinck for this reference and her and Jennifer Cromwell for a better understanding of these letters.

42 P.Scholl 12, sixth-seventh century or later, provenance unknown; O.Crum vC 11, sixtheighth century, provenance Thebes. I would like to thank Eline Scheerlinck for these references.

43 See the prisoner in Mamluk Cairo claiming bankruptcy to a Hanafi judge who would have been more likely to grant his release on this basis (Petra M. Sijpesteijn, "Financial Troubles: A Mamluk Petition," in Jews, Christians and Muslims in Medieval and Early Modern Times: A Festschrift in Honor of Mark R. Cohen, eds. Arnold E. Franklin et al. (Leiden: Brill, 2014), 352-366). Cf. Schneider, "Imprisonment," 159-16o.

44 Schneider, "Sidjn;" idem, "Imprisonment;" idem, "Freedom and Slavery in Early Islamic Time (first/seventh and second/eighth Centuries)," al-Qantara 28 (2007): 353-382.

$45 \quad$ P.Heid.Arab. II 3 o.

46 P.Cair.Arab. III 153, dated 91/710, provenance Ishqūh.

47 P.Cair.Arab. III 155, dated 91/710 provenance Ishqūh.

48 P.Horak 64.12-14, provenance al-Fayyūm.

49 P.Hamb.Arab. II 17, dating to 870-900, provenance Armant. 
dinars to the collector. Abū al-Faḍl was most probably a tax farmer himself who had failed to collect the taxes for which he was responsible in time. ${ }^{50}$

Corvée labour was another cause of confinement. Workers who were forced to fulfil some labour in their place of residence or much further away were sometimes imprisoned until the job was fulfilled or until they arrived in the place where they had to do the work. A group of workers summoned to the district capital in the second half of the seventh century is transported on boats under the supervision of a soldier and their wives are kept hostage until they have safely arrived..$^{51}$ Another kind of documentation shows how people interfere on behalf of corvée workers being confined (to be sent away) to complete some forced labour. The anystēs Senouthios in Ashmūn receives requests from different individuals to release workers kept to fulfil some forced labour, sometimes suggesting that the confinement was initiated without an order from the authorities. ${ }^{52}$ Indeed a series of orders related to other individuals instruct Senouthios to release different individuals mistakenly kept to fulfil corvée labour. ${ }^{53}$ Another petition and response show how such orders might have reached Senouthios. In 643/644, the pagarch Athanasios, Senouthios' supervisor, receives a request to prevent a specialised worker engaged in a hydraulic installation to be sent to work in Babylon. ${ }^{54}$ The latter request was reviewed positively as the order to Senouthios to release a group of workers, amongst whom the hydraulic worker, that is written on the back of the petition shows. ${ }^{55}$ A similar request dating to the seventh century asks the secretary of a village in the Fayyūm not to send some wine growers to Babylon for work related to the wheat collection. ${ }^{56}$

The apprehension of fugitive peasants who had evaded their tax payments or ceased working their tax-liable lands was a perennial concern of the Arab authorities as it had been of all Egyptian rulers before them. By running away the peasants not only deprived the fisc of their current taxes, they also threat-

$50 \quad$ P.Cair.Arab. IV 290, provenance not mentioned. For similar cases of seemingly bankrupt tax collectors in the eighth century, see the examples in Sijpesteijn, Shaping a Muslim State, $162-163$.

$5^{1} \quad$ P.Apoll. 18 , dating to $660-676$, provenance Idfū.

$5^{2} \quad$ CPR XXX 17, 20, 21.

53 Jean Gascou, "Trois orders de liberation d'époque arabe," in Papyri in Memory of P.J. Sijpesteijn, eds. A.J. Boudewijn Sirks and Klaas A. Worp, American Studies in Papyrology 40 (Chippenham: The American Society of Papyrologists, 2007), 166-167, nos. 24a-c; CPR XXX 24-27; $S B$ XX 14446; $S B$ XXVI 1635o, both cited in $C P R$ XXX pp. 239-240.

$54 \quad C P R \times X \times 18$.

$55 \quad C P R \times \mathrm{XXX} 19$.

$56 \quad S P P \times 128$ cited in Gascou, "Trois ordres," 166. 
ened the tax office's future income. With taxes being imposed on communities as a whole based on the amount of arable land available, a diminishing workforce put additional pressure on the remaining peasantry, who continued under the same tax burden with fewer hands. ${ }^{57}$ While maintaining an infrastructure to exploit as much taxable land as possible was important, the government's most pressing concern was ensuring up-to-date and accurate documentation of all tax-payers and taxable properties. Migration was permitted as long as newcomers were properly entered in the fiscal ledgers. The recording of incoming and outgoing migrants was thus at least as important. ${ }^{58}$ Presumably the fine of three solidi per person mentioned in the papyri concerned fugitives who had tried to remain below the fiscal radar in their new place of residence. ${ }^{59}$ The same amount of three solidi (as well as ten) is mentioned by literary sources as a fine for fugitives who are returned to their original place of residence. ${ }^{60}$ Administrators were also urged to apply themselves with particular diligence to the problem of fugitive peasant taxpayers. Hefty fines and even physical punishments were imposed on the officials who did not do their utmost to round up and send on fugitives hiding in their district. ${ }^{61}$ Perhaps "Samuel, the field-guard," who is sought by "Sarapion, foreman of the cultivators and the men of the same village," also played some role in supervising the workers on his fields, as well as the fields themselves. ${ }^{62}$

Other forms of dereliction could also lead to fines for government officials. Fines were incurred by pagarchs who did not transfer in a timely enough man-

57 Sijpesteijn, Shaping a Muslim State, 194. See also the requests to release prisoners so that they can help work the land (below nn. 112-116).

58 Sijpesteijn, Shaping a Muslim State, 94-99. Lists of immigrant and emigrant fugitives are asked for from the pagarch Papas in the mid-seventh century (P.Apoll. 13, provenance Idfū) and from Basileios (P.Lond. IV 1333, provenance Ishqūh) in the early eighth century.

59 P.Apoll. 13; P.Apoll. 14, both dating to 66o-676, provenance of both is Idfū.

6o Sijpesteijn, Shaping a Muslim State, 97 n. 342.

61 The village headman (lashane), Pneison son of George, promises to capture and put in prison any fugitives hiding on 'his' lands after having been assigned a heavy fine for failing to do so (P.Lond. IV 1528, dating to ca. 709, provenance Ishqūh). The duke of the Thebaid threatens any pagarch failing to bring up fugitive workers from their district a 1,00o-solidi fine or even the death penalty (P.Apoll. 9, dating to 66o-676, provenance Idfū). Officials assigned the specific task of gathering up fugitive peasants were appointed in early eighthcentury Egypt (P.Lond. IV 1332 and 1333, dating to 709, provenance Ishqūh). Abnūla, the village headman $(m \bar{a} z \bar{u} t)$, is also addressed concerning some fugitive tax-payers falling under his jurisdiction in an eighth-century Arabic letter (PERF 606).

$62 \quad$ P.Ant. III 189, dating to the sixth-seventh century, provenance Anșina. 
ner the taxes that their district owed. ${ }^{63}$ Corruption and mistreatment of taxpayers was punished even more severely by the central authorities. In his ninthcentury letter of appointment, a village headman (wäli al-qarya) is ordered to punish "anyone who imposes upon the subjects what is forbidden" (man tajāwaza māyunhī anhuilāal-ra 'ìa ). ${ }^{64}$ In one of his letters, the governor Qurra b. Sharik writes to the pagarch Basileios of Ishqūh, "if you catch one of the taxcollectors acting unlawfully towards the population or taking more than you assigned to him, then flog him a hundred times, shave his hair and beard, and fine him thirty dinars after you have recovered the excess amount."65

Several documents record how individuals, whether of their own free will or without their (explicit) permission, were held accountable for an alleged malefactor's actions, including being incarcerated. Family members could indeed be used as hostages to exact payments or compel certain behaviours. Payments or guarantees offered for the release of indebted family members have already been treated above, as well as the imprisonment of family members in lieu (cf. $\mathrm{nn} .3^{2-33)}$. Other cases of the imprisonment or involvement of family members include an eighth-century Greek papyrus that lists the names of women whose husbands had absconded. ${ }^{66}$ Whether they had become liable for the taxes on and upkeep of their husbands' lands, or functioned as guarantors for their husbands' return is not clear. In the second half of the seventh century, the pagarch Papas of Idfū is ordered to take precautions so that a group of workers summoned to the district capital will not run off. He is to transport them on boats under the supervision of a soldier and keep their wives hostage until "a letter of mine (i.e. the district's head) concerning them arrives," presumably to inform the pagarch that the men have safely arrived ${ }^{67}$ In ca. 643 the anystes Senouthios is ordered to release a certain Makaris who was imprisoned on account of some corvée labour, because his son was already sent somewhere else. ${ }^{68}$ Another papyrus letter records a wife's complaints about having been harassed, possi-

63 Reinfandt offers a list of papyri mentioning fines for tax officials ("Law and Order," 672, n. 91).

64 P.Ryl.Arab. I I 17, provenance not mentioned.

65 P.Heid.Arab. I 3.48-56, dated 91/710, provenance Ishqūh.

66 P.Horak 66; CPR XXII 35. Other examples from the Islamic period: P.Apoll. 18; 42, provenance Idfū; Frederico Morelli, "P.Brook. 26, mogli, tasse e $\xi$ Évoı. Un problema di punti di vista," Zeitschrift für Papyrologie und Epigraphik 130 (2000): 218-222; SPP X 252. Similar practices existed in pre-Islamic Egypt (examples listed in Sofia Torallas Tovar, "Violence in the Process of Arrest and Imprisonment in Late Antique Egypt," in Violence in Late Antiquity: Perceptions and Practices, ed. Harold A. Drake (London: Ashgate, 2006), 103, n. 9).

67 P.Apoll. 18, dating to $660-676$, provenance Idfū.

68 Gascou, "Trois orders," 164, 167, no. 24c. 
bly even arrested, over the taxes her husband, who was absent from his place of residence, had to pay. ${ }^{69}$ Finally, a woman arrested for her brother's misdeeds appears in a list of prisoners. ${ }^{70}$

Beyond family members, others in the culprit's environment could also be apprehended. The boatman in the service of a shipper about whose tax payments in his place of residence there was some uncertainty was arrested in the second half of the seventh century. ${ }^{71}$ Similarly, the monk working the lands belonging to the monastery of Bawit was arrested because the taxes due on the lands were not paid. ${ }^{72}$ It is not clear whether those standing guarantor for fugitives listed in eighth-century papyri did so 'with their body' or financially. ${ }^{73}$ Interestingly, Islamic law prohibits offering guarantees against one's life or body parts. In other words, one cannot agree to be imprisoned or undergo physical punishment in someone else's stead. ${ }^{74}$

Guarantee documents in which individuals stand guarantor for payments or services to be provided by a third person abound in the papyrological record. Guarantee declarations appear at the end of debt acknowledgements, obliging a third party to pay the money owed in the event that the debtor is unable to do so, ${ }^{75}$ as for example in an eighth-century Coptic letter in which the sender states that he will make sure no one will arrest the recipient of the letter, thereby standing guarantor for (or already having paid) anything the recipient owed. ${ }^{76}$ Above (nn. 40-42) cases in which imprisoned debtors are released or request the release through a guarantor who pays off or guarantees to pay off their debt. An interesting case is related in a letter dated to between 671 and 730 . The sender rebukes the addressee's accusation of having incarcerated a certain 'Abd al-Rahmmān for whose release he had worked

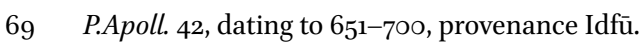

$70 \quad S P P \times 252$, dating to the Arab period, provenance al-Fayyūm.

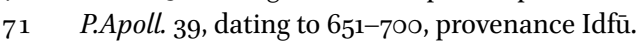

$72 \quad$ P.Kölnägypt II 43, seventh-eighth century, provenance Bawiț.

73 See for example P.Lond. IV 1518, 1519, 1521, provenance Ishqūh. Cf. P.Apoll. 13.1, commentary, provenance Idfū.

74 Apparently this did occur in Roman Egypt (Torallas Tovar, "Violence," 103, n. 10). The Islamic prohibition of debt slavery seems related (Irene Schneider, Kinderverkauf und Schuldknechtschaft:Untersuchungen zur frühen Phase des islamischen Rechts, Abhandlungen für die Kunde des Morgenlandes vol. 52, no. 1 (Stuttgart: Kommissionsverlag Franz Steiner, 1999), 57-278; idem, "Freedom," 362 ), as is the discussion concerning selling family members and other free individuals into slavery (Schneider, "Freedom," 369-377).

75 CPR XXVI 19.13-14, ninth century, provenance al-Fayyūm; 30. 13, dated 1188, provenance al-Ashmūnyn. Further examples are listed in the commentary.

$76 \quad$ O.Vind.Copt. 184. I would like to thank Eline Scheerlinck for this reference. 
hard at the addressee's request. The addressee had complained that the sender did not work fast enough in organising that 'Abd al-Rahmmān, who is kept by a third person, is set free. The sender relates that he only managed to secure 'Abd al-Rahmmān's release by promising that the addressee guarantees to present 'Abd al-Rahmmān. ${ }^{77}$

Guarantees could also be given for those whose whereabouts were being monitored and who were likely to disappear. That peasants and workers contracted by the Arab-Muslim authorities who were prone to running away were additionally controlled through guarantees has already been discussed above. Guarantees also had to be provided for released prisoners who required ongoing monitoring. Such documents state that the guarantor will, when requested, report with the released prisoner day and night at the prison. ${ }^{78}$ Justus, a flax worker, frees Johannes, a dyer, from prison and guarantees he will work in the service of another dyer according to the conditions of his guild, bearing the responsibility for gains or losses himself. If Johannes fails to show up at the workplace or to meet these conditions, Justus will report with him at the prison "where he received him."79 In requests for safe-conducts allowing the holders to travel freely, guarantors took responsibility for the return of the travellers and/or the taxes they had to pay in their place of residence. ${ }^{80}$

Guarantors generally promised to pay a financial recompense in the case of a no-show or non-payment. ${ }^{81}$ Sometimes this could, of course, lead to the guarantor landing in gaol if he could not pay the promised sum. In the second half of the seventh century, the duke Zubayd b. Khudayj ordered the pagarch Papas of Idfü to send the bearer of his letter to an unknown destination, demanding guarantors to make sure the bearer left. ${ }^{82} \mathrm{~A}$ seventh/eighth-century papyrus

$77 \quad C P R$ XVI 27.

$78 C P R$ XXIV 32, dating to 651, provenance Madīnat al-Fayyūm; $S B$ VI 9146, eighth century, provenance Ihnās. This phrase/practice is also used in Byzantine guarantee declarations. For examples from narrative sources, see Mathieu Tillier, "Les prisonniers dans la société musulmane (IIe/VIIIe-IVe/Xe)," in Dynamiques sociales au Moyen Âge en Occident et en Orient, ed. Elisabeth Malamut (Aix-en-Provence: Publications de l' Université de Provence, 2010), 191-212.

$79 S B$ XVI 12717, dating to 640-650, provenance Ihnās.

8 o $\quad$ E.g. Jakob Krall, "Neue koptische und griechische Papyrus," Recueil de travaux relatifs à la philologie et à l'archéologie égyptiennes et assyriennes 6 (1885): nos. 1-4; P.KRU 115; 119, both mid-eighth century, provenance Jēme; P.Mon.Epiph. 255; 458, both seventh century, provenance of all is Jēme.

81 Most guarantors promise to pay the money or goods owed instead of the debtor if the latter is unable to do so. E.g. P.KölnÄgyp. II 37, seventh century, provenance Bawīṭ.

P.Apoll. 7 , dating to $676-725$, provenance Idfū. 
apparently illustrates both situations in a double guarantee involving three people. In this document, a man promises, if so requested, to bring a woman to prison who herself is acting as a guarantor for her husband, a worker (Gr. ergatēs) who had been taken to Fusțât, and to pay four holokottinoi if he fails to do so. ${ }^{83}$

Goods or property could be confiscated in the absence of the offender or debtor, or impounded until a payment had been made. In a group of letters dating to 101-102/719-720, a certain 'Ammār, seemingly some kind of bailiff, is ordered to return goods taken as guarantees - a boat filled with straw, some animals - to their owners. ${ }^{84}$ 'Ammār is additionally instructed not to imprison (Ar. habasa) a tax-payer because he was too frail (Ar. haram wa-maksūr), although his taxes were overdue, but to take a surety from him instead (Ar. khudh minhu rahn). ${ }^{85}$ In the seventh-eighth century two Muslim officials confiscated the possessions of a certain Georgios who had absconded. ${ }^{86}$ It is not clear whether the goods were taken in lieu of the amounts outstanding or as a ransom to force Georgios to pay (or show) up. Another early eighth-century document reports how two tax-collectors confiscated some fodder from the fields of the inhabitants of a village who had avoided paying taxes by running away. ${ }^{87} \mathrm{On}$ the other hand, flexibility is also in evidence: a demand to present a woman to the administration states that nothing should be taken from her. ${ }^{88}$

Beyond the role of the prison as a place to hold people until they paid their due, additional physical sanctions could be applied in prison. In some cases these served to urge the prisoners on to settle the payments which were the cause of their imprisonment. Such a practice is known to have been applied also in Late Byzantine Egypt. ${ }^{89}$ In several letters prisoners complain about the severe treatment they received in prison..$^{90}$

Theft is another crime the papyri frequently report on. Some instances of theft were brought before the authorities, others seem to have been dealt with outside the official system, or at least in a more informal manner. The decision to handle a case within or without the judicial system could be influenced by the importance of the people involved. In a ninth-century letter the

\footnotetext{
$83 \quad C P R$ IV 102, seventh-eighth century, provenance not mentioned.

84 Diem, "Dienstschreiben," nos. a, c and d.

85 Diem, "Dienstschreiben," no. b.

86 Discussed in Sijpesteijn, Shaping a Muslim State, 161-162.

87 PERF 606, provenance probably al-Fayyūm.

88 PERF 699, ninth century, provenance not mentioned.

89 Torallas Tovar, "Violence," 101. See also the instances of torture, the use of chains and additional hardship in Roman prisons (Krause, Gefängnisse, 276-285, 291-294). See below, the discussion on torture in the section "infrastructure."
} 
sender reports on the theft of some straw (Ar. tibn). He accuses a manumitted slave from his household and asks the addressee, "If you see fit to beat him (Ar. taqra'ahu) and to frighten him with a beating, then do so! Perhaps he will return what he took." Finally, he asks the addressee, who obviously held some position of authority, although it is not clear whether it was in the legaladministrative system, to tell the accused to "keep away from our house." ${ }^{91}$ In another eighth-ninth-century (Arabic) letter, the owner of an estate asks the addressee of his letter to allow him to deal with a theft of 70 bushes of straw on his property himself rather than bringing the case to the attention of the Muslim-Arab authorities. ${ }^{92}$ Again, a thief who stole wheat from the bishop's granaries is charged by the bishop, but if he reoffends he will be led to the administrative offices of the praetorium. ${ }^{93}$ There is also no indication that an official is handling the case of the "cooks and leather-workers" who are sought "in the matter of the sheep which have been stolen from Pouamp" in sixthseventh-century Anșinna. ${ }^{94}$

Other cases of theft, however, did end up in the official system. In an eighthcentury Greek papyrus from the Fayyūm oasis a list of prisoners appears with the villages they are from and the crimes they have committed. Amongst others, the following persons are mentioned: "Aphou son of Biktor and Phol(?) son of Damaianos from the village of Sebenetou, because of robes stolen from the shop of Mobaros; Bartholomaios son of Epimachos and Kollouthos son of Phoibammon from Kieratou, because of wine stolen from the shop of the brother; Leontios son of Denouthios and Anastasia wife of Senouthios from Syrou, because of a bull stolen from Allaret"95 - showing the degree to which the state did not limit its interference to capital crimes, but also involved itself in petty crimes, such as small-scale theft. Another list includes "Apaioulios, carpenter, (imprisoned) because of a cut acacia tree," which he presumably did without permission. ${ }^{96}$ The case of the thieves who are mentioned in an eighth-century document in connection with crucifixion must have been much more serious, perhaps involving highway robbery, as Lucian Reinfandt has suggested. ${ }^{97}$

\footnotetext{
91 Chrest.Khoury I 80, provenance unknown.

92 Karl Jahn, "Vom frühislamischen Briefwesen," Archiv Orientální 9 (1937): 153-200, no. 17, eighth-ninth century, provenance unknown.

93 Foss, "Egypt under Mu’āwiya," 266.

94 P.Ant. III 189.

95 P.Horak 64.

96 P.Horak 66, eighth century, provenance al-Fayyūm.

97 Reinfandt, "Law and Order."
} 
Another class of crimes recorded in the papyri are associated with the disturbance of public order. Fights and physical altercations are one example. ${ }^{98}$ Punishments functioned not only to reprimand the offender, but to deter others. "Punish the man who tricked two visitors and make him an example for others!" writes an official to a lower administrator in a ninth-century letter. ${ }^{99}$

After this overview of the kinds of crimes and punishments seen in documents from the early Egyptian countryside, we should examine what arrangements and instruments were in place for the punishment and incarceration of criminals.

\section{Infrastructure}

Not much information can be extracted from the papyri about the kind of physical structures that were used to hold people. Existing prisons continued to be used by the conquerors. Whether the references in Greek and Coptic documents to public prisons (Gr. dèmosia phylakē) refer to institutions falling under the Arab administration or institutions that continued to be run by those in charge of them in the pre-Islamic period is not clear. ${ }^{100}$ The rule in mediaeval Egypt, as elsewhere in the early Muslim empire, seems to have been to convert houses and other improvised buildings into prisons. ${ }^{101}$ References in the papyri to prisons with terms suggesting actual buildings (Ar. s. sijn; pl. sujün; Gr./Cp. phylakē), however, imply that these were distinct and recognisable, and more or less permanent. The order in an early eighth-century letter not to approach the prison indicates a fixed and identifiable building. ${ }^{102}$ On the other hand, the fact that prisoners were sometimes shackled perhaps denotes that these 'prisons' were less suitable for long-term confinement or only functioning to

\footnotetext{
$98 \quad$ P.Horak 64.14; 66.13, eighth century, provenance al-Fayyūm.

99 P.Ryl.Arab. I I 12, ninth century, provenance Ramjūs, al-Ashmūnayn.

$100 B G U$ III $75^{2}$, sixth-seventh century, provenance al-Fayyūm; $C P R$ XXII 4 , dating to midseventh c., provenance al-Ashmūnayn; $C P R$ XXIV 32, dating to 651, provenance al-Fayyūm; $S B$ I 4659, dating to 668 (or 653), provenance al-Fayyūm; $S B$ VI 9146, eighth century, provenance al-Ashmūnayn. See also the mention of a "prison of Antinopolis" (Gr. phylakē tēs antinoou) (P.Apoll. 63, dating 650-699, provenance Idfū).

101 Anthony, "Domestic Origins," 571-577 and Schneider, "Imprisonment," 166-167 discuss the many literary references to the conversion of houses into prisons especially during the conquest period. The only prison in Fusțāt that al-Maqrīzī (d. 845/1442) lists was a building that had previously served as a house, police station and storage facility (al-Mawāंiz wa-l-itibār fì dhikr al-khițaț wa-l-äthār, ed. Ayman F. Sayyid (London: al-Furqan Islamic Heritage Foundation, 2002-2003), 3:597-598).

102 Sijpesteijn, Shaping a Muslim State, no. 19, provenance al-Fayyūm.
} 
hold prisoners in the absence of more suitable facilities. ${ }^{103}$ Once a building was designated as a prison, however, it seems it could function as such for several generations. ${ }^{104}$ Other words used for these structures relate to the Arabic root $h-b$-s, referring to the act of detention but give no clues as to the context in which this took place. ${ }^{105} \mathrm{~A}$ case of house arrest seems to be suggested in a ninth-century letter in which the addressee writes, "For a year I was unable to leave the house, since the new official arrived."106

Prisons were 'open' structures from where written communications were exchanged with the outside world and visits were allowed from outsiders. ${ }^{107}$ Prisoners regularly wrote petitions requesting their own release. ${ }^{108}$ Orders for commercial transactions were also given from prison. ${ }^{109}$ The transitory nature of prison stays is confirmed by the plans prisoners, who were obviously not expecting extended confinement, made with their correspondents. ${ }^{110}$ There were limits though, as an early eighth-century Arabic letter prohibiting someone from approaching the prison suggests. ${ }^{111}$

Confinement could indeed have serious economic repercussions, as inmates were prevented from working. This was especially difficult for agricultural workers, whose activities were tied to the land and the seasonal rhythm and consequently hard to intermit. On several occasions, attempts were made to

103 Stocks or irons are mentioned (P.Mon.Epiph. 181; 219) as well as other forms of being tied up (P.Mon.Epiph. 177). All these papyri date to the seventh century and originate in Jēme. When the duke of the Thebaid asks the pagarchs to hunt down fugitives, he orders to "bring them back in shackles" (P.Apoll. 9, dating to 66o-676, provenance Idfū).

104 Anthony, "Domestic Origins," 572.

105 As is the case in the Qurān (Q 5:106; 11:8). Cf. Schneider, "Imprisonment," 166.

106 ... fì al-manzil sana wa-mà aqduru an akhruja ilà al-țarīq mundhu wașala al-'̌amil al-jadìd (P.Ryl.Arab. I VI 5). Cf. the report of similar cases in the literary sources as quoted by Schneider, "Imprisonment," 167.

107 Literary accounts offer similar evidence for the porousness of prisons (Mathieu Tillier, "Prisons et autorités urbaines sous les Abbassides," Arabica 55 (2008): 387-408; idem, "Prisonniers;" Schneider, "Imprisonment," 168). See also the account of Bakkār b. Qutayba (d. 270/883) who was able to recite hadiths to an audience through the window of his house where he was kept locked up (translated in Matthieu Tillier, Vies des cadis de Mișr 237/851-366/976, Cahier des Annales Islamologiques 24 (Cairo: Institut Français d'Archéologie Orientale, 2002), 70).

108 See the unedited P.Vindob. A.P. 3002, ninth, which I am preparing for publication, in which a prisoner explains that he has been taken to prison by some farmers, presumably because of an unpaid debt. Cf. P.Mon.Epiph 176; 177 , both seventh century, provenance of both is Jēme.

109 To make payments to a third person (P.Mon.Epiph. 177, seventh century, provenance Jēme).

110 "We will take six soldiers and come north ..." (P.Mon.Epiph. 177, seventh century, provenance Jēme).

111 Sijpesteijn, Shaping a Muslim State, no. 19, provenance al-Fayyūm. 
get prisoners released so that they could perform their tasks on their farms. In an undated Coptic ostracon, the sender asks that a prisoner who is needed in "the season of work" be set free."12 An agent responsible for agricultural lands belonging to the monastery of Bawit asks the abbot in a seventh-eighthcentury Coptic papyrus to pay his tax debt so that the agent will be released and the work he has to do on the land not endangered. ${ }^{113}$ In a Greek letter dating to $643^{-644}$ to the anystes Senouthios in Ashmūn the sender protests that two brothers are ordered simultaneously to work in Babylon as it would endanger the care of their animals. The sender asks that a replacement is sent to the capital for one of the brothers. ${ }^{114}$ In a ninth-century petition to an amirr, the sender writes that his harvest failed because he was imprisoned and asks to have his tax debt written off. ${ }^{115}$ Similarly, the writer of an eighth-century letter, seemingly the agent of an estate-holder, writes that he was unable to take care of his tasks because he had been imprisoned and fined. ${ }^{116}$ Besides agricultural work, the completion of expert craftsmanship was threatened by confinement. Specialised handworkers were in demand by the Arab authorities to work on building projects in the provincial capital or one of the other cities in the empire or in the ship wharfs in Alexandria, Fusțât, or Qulzum. The Arab authorities' orders for labour are often accompanied by the demand that no money or restitution can be sent in lieu of the craftsmen. In petitions requesting the release of specialised workmen it is stated that their expertise cannot be missed in the community. ${ }^{117}$

As a general rule, prisoners had to be provided for by outsiders. ${ }^{118}$ In a seventh-century Coptic letter, an undefined number of prisoners ask that their rations, as well as bread, be sent to the prison guard. ${ }^{119}$ Shortages of supplies are a frequent sore point, with prisoners regularly complaining of being 'hungry.'120

\footnotetext{
112 Walter Crum, Coptic Ostraca from the Collections of the Egypt Exploration Fund, the Cairo Museum and Others (London: The Egyptian Exploration Fund, 1902), no. Ad 27, provenance and date unknown.

113 P.KölnÄgypt II 43, seventh-eighth century, provenance Bawiț.

114 CPR XXX 20.

115 P.Khalili I 16, provenance not mentioned.

116 P.Khalili I 14, provenance not mentioned.

$117 C P R \mathrm{XXX} 18$ is a request to prevent a specialized hydraulic worker who is responsible for a cistern to be sent to Babylon for work. Dating to 643-644, provenance al-Ashmūn.

118 This was also the case in the Roman period (Krause, Gefängnisse, 290-291).

119 P.Mon.Epiph. 177, seventh century, provenance Jēme.

120 P.Mon.Epiph. 219, seventh century, provenance Jēme; P.Apoll. 18, dating to 66o-676, provenance Idfü. For similar complaints recorded in narrative sources, see Matthieu Tillier, "Vivre en prison à l'époque abbasside," Journal of the Economic and Social History of the Orient $5^{2}$ (2009): 635-659. For examples from hunger prisoners in Roman prisons, see Krause, Gefängnisse, 279-282.
} 
More fortunate prisoners made their own arrangements. An Arabic order of payment dated 262/876 records the delivery of $11 / 61 / 48$ dinar to an imprisoned druggist for his monthly maintenance. ${ }^{121}$ In other cases provisions seem to have been provided through impositions. A seventh-century Greek papyrus contains a list of mattresses intended for prisoners delivered by villages in the Fayyūm. ${ }^{122}$

Transportation to and from the place of confinement could take place by different means. The Arab administration seems to have employed a fleet to transport people and goods up and down the Nile, which also carried prisoners. ${ }^{123}$ Caulkers from Idfū ordered to work on the wharves, who had run away, were returned on boats. ${ }^{124}$ A letter dated 102/721 refers to the female writer being "kept prisoner on our boats (sujinnā fi marākibināa)," though the context is admittedly unclear. ${ }^{125}$ The barid, the official postal service, which reported on cases of misbehaviour by government officials, as is recorded in an early eighth-century Arabic papyrus, ${ }^{126}$ was on occasion used to move prisoners, although specific references to Egypt are lacking. ${ }^{127}$ Soldiers, guards and aides were employed in the service of the administration to capture and guard prisoners. These seem to belong to the general personnel in the entourage of the pagarch. ${ }^{128}$ Guards (Ar. hăris/hurrās; Gr. phylax/phylakes) often occur in the papyri. Although their functions are too diverse to associate them exclu-

121 P.Cair.Arab. v 351, provenance al-Ashmūnayn, with corrections by Werner Diem, "Philologisches zu arabischen Dokumenten, II: Dokumente aus der Sammlung der Egyptian Library in Kairo," Zeitschrift für Arabische Linguistik 56 (2012): 73-74.

122 Hermann Harrauer, "Matrazen für Gefangene," Archiv für Papyrusforschung 33 (1987): 6972 .

123 They are described as 'fishing boat' (Gr. halieutikos). Prisoners transported on boats: P.Apoll. 18, dating to 66o-676, provenance Idfū. Administrative tours conducted on boats: P.Apoll. 12, dating to 661-676, provenance Idfū. Pagarch Papas is asked to provide a boat for a tax collection campaign amongst the Blemmyes in the eastern desert (P.Apoll. 15, dating to $660-676$, provenance Idfū).

124 P.Apoll. 9, dating to 66o-676, provenance Idfū.

125 Alia Hanafi, "An Arabic Will Written on a Ship," in Proceedings of the Twenty-Fifth International Congress of Papyrology, Ann Arbor 2007, ed. Traianos Gagos, American Studies in Papyrology (Ann Arbor: University of Michigan Press, 2010), 299-306, provenance unknown.

126 P.Cair.Arab. III 153, dated 9o/709, provenance Ishqūh. Discussed by Adam Silverstein, Postal Systems in the Pre-Modern Islamic Worlds (Cambridge: Cambridge University Press, 2007) 71-72. Under caliph al-Manșūr (r. 136-158/754-775), the barìd collected intelligence reports for the authorities (Silverstein, Postal Systems, 73).

127 Silverstein, Postal Systems, 57, 98.

128 Sijpesteijn, Shaping a Muslim State. See also the discussion in Reinfandt, "Law and Order," 661. 
sively with the guarding of people in an administrative context, it seems safe to assume this was also part of their role. ${ }^{129}$

Whether the accounts of physical abuse as reported in several letters should be taken entirely at face value is open to question, since they often appear in the context of petitions. ${ }^{130}$ We do have a reference to captured fugitives being flogged in prison, though there it is by no means clear that this was a frequent occurrence. ${ }^{131}$ Prisoners could also be shackled during transport or while in prison. ${ }^{132}$ Similarly, distinctions were made between prisoners deemed less likely to escape and those who needed to be treated with special care. Fugitives who had returned to their villages of residence - thereby being easier to locate - were 'merely' returned to the district's capital, while fugitives who had settled in places other than their place of origin were to be shackled before they were sent on. ${ }^{133}$

Solving Conflicts: Administrative Law and Beyond

Cases tried before the law and its representatives as seen in the papyri fall into two categories: (1) civil litigation, in which the case was initiated by the injured party through petitions and the like, and (2) criminal cases, involving serious sentences such as incarceration, fines and execution. In the beginning of the period under discussion Muslim legal institutions and infrastructure, such as courts, judges (Ar. s. qā

129 See the discussion by Albert Dietrich, Arabische Briefe aus der Papyrussammlung der Hamburger Staats- und Universitäts-Bibliothek (Hamburg:J.J. Augustin, 1955), 47-48; Adolf Grohmann, "Der Beamtenstab der arabischen Finanzverwaltung in Ägypten in früharabischer Zeit," in Studien zur Papyrologie und antiken Wirtschaftsgeschichte: Friedrich Oertel zum achtzigsten Geburtstag gewidmet, ed. Horst Braunert (Bonn: R. Habelt, 1964), 131; Sijpesteijn, Shaping a Muslim State, 306.

130 See for example a claim of having the hands maimed and having been left to urinate without being able to cover oneself (P.Mon.Epiph. 178); of having been "hung up backwards" (P.Mon.Epiph. 177); of having been kept in stocks (P.Mon.Epiph. 181), all seventh century, provenance of all is Jēme.

131 A fugitive receives 40 lashes in prison (P.Lond. IV 1384, dated 710, provenance Ishqūh).

132 Stocks or irons in prison are mentioned (P.Mon.Epiph. 181; 219), as well as other forms of forcible restraint (P.Mon.Epiph. 177, all dating to the seventh century, provenance of all is Jēme). Fugitives being returned to their place of residence: P.Apoll. 9, dating to 66o676 , provenance Idfū. See also the unfortunate who claims to have been "put in irons" (Sijpesteijn, Shaping a Muslim State, no. 31, dating to ca. 730, provenance al-Fayyūm). For similar complaints recorded in narrative sources, see Tillier, "Vivre en prison."

133 P.Apoll. 9, dating to 661-676, provenance Idfū. 
from the later period, were still in development. The first documentary evidence of $q \bar{a} d \bar{\imath}$ justice being applied in Egypt dates from $141 / 75^{8-759}$ from the capital Fustạt. ${ }^{134}$ References to $q \bar{a} d \bar{i}$ s in the Egyptian countryside date to the eighth century, but it is not clear in what capacity they were operating there. ${ }^{135}$ Only in the ninth century is a systematised, $q \bar{a} d \bar{l} \bar{\imath}$-based legal system observable. ${ }^{136}$

Throughout the period under study, most criminal cases, as well as questions of public order, were in practice dealt with by officials in charge of public security (governors, district officials, village headmen), as had been the case in the Byzantine period. ${ }^{137}$ People ended up in the hands of the administrative authorities in two ways. The authorities initiated the punishment of offenders such as tax refugees, but also corrupt officials who had overcharged or mistreated tax-payers. Conflicts between private individuals, but also claims of mistreatment, abuse, theft or assault by one individual against another, were brought before officials in person or via a written petition or complaint. ${ }^{138}$

These administrative officials assigned discretionary punishments on the basis of a simplified procedure, without the formal rules of evidence established in later Islamic legal theory. In some cases lower officials might then examine the cases, gathering evidence and calling in witnesses. This procedure, summarised in later legal texts under the heading of siyassa and tazir

134 The famous letter written by governor Mūsā b. Ibrāhīm (in office 141/758-759) mentions qāộ̄ Ghawth b. Sulaymān (Tillier, "Pagarque," 31 ff., provenance Aswān). A small note sent by Ghawth b. Sulaymān exists as well (Tillier, "Deux papyrus," no. 1, provenance Fusțāț). Literary sources discuss earlier appointments in Fusțāt. 'Amr b. al-ĀAs is said to have appointed Qays b. Abī al-Āṣ as the first $q \bar{a} d \grave{c}$ in Fusțāṭ immediately following his conquest of the country in 23/643 (Muhammad b. Yūsuf al-Kindī, Kitāb al-wulāt wa kitāb al-qud̄āt, ed. Rhuvon Guest as: The Governors and Judges of Egypt (Leiden: Brill, 1912), 300-301).

135 Sijpesteijn, Shaping a Muslim State, 403.

136 Tillier, "Pagarque," 20, 35; idem, Histoire des cadis égyptiens (Ahbār quḍāt Mișr) (Cairo: Institut français d' archéologie orientale, 2012), introduction; Petra M. Sijpesteijn, "Delegation of Judicial Power in Abbasid Egypt," in Legal Documents as Sources for the History of Muslim Societies: Studies in Honour of Rudolph Peters, eds. Maaike van Berkel, Léon Buskens and Petra M. Sijpesteijn (Leiden: Brill, 2017), 61-84. For court orders from the tenth century, see above n. 21.

137 Bernhard Palme, "The Imperial Presence: Government and Army," in Egypt in the Byzantine World 300-700, ed. Roger S. Bagnall (Cambridge: Cambridge University Press, 2007), 256-257; Keenan, Manning and Yiftach-Firanko, Law and Legal Practice, 470-471.

138 Documents referring to cases brought in front of the authorities use verbs with the meaning "report" (balagha, dhakara, akhbara) which could be in oral or written form, but can also refer explicitly to the presence of the plaintiff in person. See for example the letter dated 9o/709 in which the sender mentions that the addressee sent him someone from his district with a request or complaint (qad arsalta ilayya bi-l-nabațī) (P.Cair.Arab. III 152.34, provenance Ishqūh). 
and pertaining to offences not covered by the shari'a, continued to exist in the fully developed Islamic legal system. ${ }^{139}$ The exclusive presence in the Arabic documentation of administrative lawmakers should thus not be straightaway explained as evidence for the overall absence of a legal system based on Islamic premises. ${ }^{140}$

Conversely, the appearance of legal documents drawn up according to an Arabic-Muslim legal practice - starting directly following the Arab conquest of Egypt $^{141}$ - does not necessarily imply the presence of an Islamic legal infrastructure. In other words, legal documents could be drawn up and legal transactions executed according to Islamic law without the participation of a Muslim court, judge or other formal representative of the official legal system. Where and by whom knowledge about how to document legal transactions correctly was located in the countryside remains a question to be examined. Muslim legal authority was also present in the order of (professional) witnesses instituted in 174/79o in Fusțăț. The names of witnesses verifying the legal transactions recorded in the documents appear from the late eighth century onwards at the end of these documents. ${ }^{142}$ Verification and registration of the transaction documents, as well as the handling of disputes arising from the transactions themselves would have been handled by the court in Fusțât.

Beyond the administrative framework, local power-brokers - religious leaders, estate-holders, village headmen and representatives of other socio-economic forces - played a role in cases of litigation, covering, initially, the criminal law as well. Disputes arising from assault, theft and other (alleged) crimes were solved with their help. Accused and convicted criminals turned to them for assistance, and they also figured in the tracking down, conviction and punishment of offenders. This was a continuation of their role in the Byzantine legal system, where both public law courts and legal-administrative functionar-

139 Peters, Crime and Punishment, 67-68.

140 While hardly any evidence of the application of hadd punishments occurs in the papyri for the exception to this rule, see the reference to crucifixion in relation to thieves (P.Ryl. Arab. I I 14, eighth century, provenance not mentioned) - this can also be related to the reluctance of Muslim society to apply such punishments (Peters, Crime and Punishment, 73). For a definition of 'Islamic law' as the legal system of a Muslim polity without the necessary involvement of a qā $\underline{\imath} \bar{\imath}$, see Tillier, "Pagarque," 33 .

141 See the list of tax receipts (earliest dated to 22/643), quittances (earliest seventh-eighth century) and legal claims or debt acknowledgements (earliest dated 42/662) listed in Jelle Bruning, "A Legal Sunna in Dhikr Haqqs From Sufyanid Egypt," Islamic Law and Society 22 (2015): 1-23.

142 Geoffrey Khan, Bills, Letters and Deeds: Arabic Papyri of the seventh to eleventh Centuries (Oxford: Khalili Collections, 1993), 173. 
ies existed side by side with institutions run by heads of local religious and economic constituencies (abbots, bishops, large estate-holders). ${ }^{143}$

That an indigenous legal infrastructure continued to operate after the arrival of the Arabs is clear from references to judges (Gr. s. dikastēs) and law courts (Gr. s. dikasterion) in Greek and Coptic papyri dealing with cases of property and personal law, from the seventh and eighth centuries. ${ }^{144}$ Even later, in keeping with their dhimmi status, Egyptian Christians and Jews maintained their own law courts, which dealt with issues pertaining to personal status, such as marriage, divorce and inheritance, as well as ritual and personal behaviour. ${ }^{145}$ Affairs relating directly to the church or other non-Muslim religious institutions would also typically have been dealt with internally. ${ }^{146}$ Although the

143 For legal authorities outside the public system, see for example the early seventh-century documents related to Pisenthios bishop of Coptos (in office 599-632) (Terry G. Wilfong, Women of Jeme: Lives in a Coptic Town in Late Antique Egypt (Ann Arbor: University of Michigan Press, 2002), 38-41), or those pertaining to the epoikia, estates (Jean Gascou, "Les grands domaines, la cité et l' État en Égypte Byzantine," Travaux et Mémoires 9 (1985): 1-9o). Cf. Olivia Robinson, "Private Prisons," Revue international des droits de l'antiquité 15 (1969): 389-398.

144 E.g. a document dated to 648 mentions a judge ( $S P P \mathrm{XX} 243$, provenance Medinnat alFayyūm). A Greek contract of sale attests a dikasterion ( $s$ B vi 8987 , dating to $644-645$, provenance al-Bahnāsa). See also the agreement dated 647 concerning a mortgaged house in which judges and a court are mentioned ( $s B$ VI 8988 , provenance Idfū). In the second half of the seventh century a tribunal and judge were involved in the decision in a dispute between a son and his mother (P.Apoll. 61, provenance Idfü). A Greek-Coptic will dated ca. 695 mentions the court (P.KRU 65, provenance Jēme). Eighth-century Coptic and Greek sales contracts from Thebes mention a court (dikasterion) ( $C P R$ IV 26, eighth century; $P . K R U 38$, dating to the first half of the eighth century; P.KRU 21, dating to $725 ; P . K R U 38$, dating to $725-726 ; P . K R U 13$, dating to $733 ; S B$ I $5609+P . K R U$ 106, dating to $734 ; S B$ I 5558 $+P . K R U$ 5, dating to $733-748 ; S B$ I 5601 + P.KRU 9o, dating to 747-748; $S B$ I $5557+P . K R U$, dating to $749 ; P . K R U 11$, dating to $753 ; P . K R U 20$, dating to $759 ; S B$ I $5596+P . K R U$ 84, dating to 770 ; $S B$ I $5606+P . K R U$ 99, dating to 780 ) and judges (dikastēs) ( $S B$ I 5590 , dating to 723 ). For a discussion on how to read these references, see Michael Morony, "Religious Communities in the Early Islamic World," in Visions of Community in the Post-Roman World: The West, Byzantium and the Islamic World, 300-1100, eds. Walter Pohl, Clemens Gantner and Richard Payne (London: Routledge, 2012), 155-163.

145 Uri Simonsohn, A Common Justice: The Legal Allegiances of Christians and Jews Under Early Islam (Philadelphia: University of Pennsylvania Press, 2011). For a system based on personal (rather than territorial) law which developed in the late antique Near East and Mediterranean, see Morony, "Religious Communities."

146 But see the canonical law codes threatening those ecclesiastical officials who turn to the Muslim courts to raise church affairs (Uri Simonsohn, "Blessed are the Peace Makers: An Ecclesiastical Definition of Authority in the Early Islamic Period," in Mediations on Authority, ed. David Shulman, Martin Buber Society of Fellows Notebook Series (Jerusalem: Magnes Press, 2013), 101). Cf. Reinfandt, "Law and Order," 667, n. 67 which quotes alMaqrīzìs remark that the Egyptian Christians had their own courts to deal with internal 
courts that operated under the first decades of Muslim rule were simply a continuation of pre-Islamic institutions, rather than distinctive dhimmi courts, with the development of Islamic legal institutions, Christian and Jewish courts and legislation specialised as well. ${ }^{147}$ Channels for informal arbitration of conflicts, in family but also in civil law cases, existed throughout the period in parallel with the public system, also in its fully developed form. ${ }^{148}$

\section{Professionalisation and Islamicisation}

The period under discussion witnessed major political and cultural change that impacted the way legal conflicts were dealt with and by whom. Who was in charge of the assignment and execution of punishments and how did the state's competence relate to private initiative in this domain?

Following the arrival of the Arabs in Egypt in 639 daily life seems initially to have been little affected in the Egyptian countryside, where Byzantine institutions and their associated officials continued to function. ${ }^{149}$ In the late Byzantine period, large land-owners had taken over many of the public functions of the central state, including policing and dealing with crimes committed within their domains and directly affecting their property or interests. Thus, in a sixthseventh-century Greek text the count (Gr. komēs) Kallinikos is asked to gather the individuals against whom claims have been raised from "his villages."150

legal affairs. A Coptic document dating to 698 or later refers to a monk expelled from the monastery because he 'despised the habit and was not able to keep the commandments of our holy fathers' (P.CLT 1; translation from Leslie MacCoull, Coptic Legal Documents: Law as Vernacular Text and Experience in Late Antique Egypt (Tempe: Arizona Center for Medieval and Renaissance Studies, 2009), 44, provenance Jēme).

147 Mikhail claims that no sufficiently developed Coptic law code existed before the tenth century to serve such specialised Christian law courts headed by Coptic hierarchy (Maged S.A. Mikhail, From Byzantine to Islamic Egypt (London/New York: I.B. Tauris, 2014), 151$152)$.

148 Amongst the countless examples in the papyri of arbitration, see for example the wife who is praised for having reconciled her husband with his children and his brother's children (P.Ryl.Arab. I VI 11). Another man is asked to intervene with his sister who has sworn to deal with a case concerning a third person but has failed to do so (P.Ryl.Arab. I vi 14). Both date to the ninth century and have no provenance mentioned.

149 For the system put in place by the conquerors combining continuity and change as well as the administrative changes implemented fifty years later in Egypt, cf. Petra M. Sijpesteijn, "The Arab Conquest of Egypt and the Beginning of Muslim Rule," in Egypt in the Byzantine World 300-700, ed. Roger S. Bagnall (Cambridge: Cambridge University Press, 2007), 437459; Marie Legendre, "Neither Byzantine nor Islamic? The Duke of the Thebaid and the Formation of the Umayyad State," Historical Research 89 (2016): 3-18.

150 P.Ant. III 189, provenance is Anșinna. 
The indigenous religious leadership and land-based socio-economic élite not only survived the conquest, but formed an overlapping power structure actively engaged with and integrated into the Arab-Muslim administration. ${ }^{151}$ Along with the local administrative functions they continued to perform, this élite handled penal and personal law cases, as well as issues of public order. Cases could also be brought before local figures of authority outside the Arab administration, with indigenous élite members continuing to enjoy a large degree of judicial autonomy. ${ }^{152}$ The sender and addressee of a seventh-century Coptic letter appear to have kept each other's client(s) prisoner in a seemingly private setting. ${ }^{153}$ Similarly, amongst the individuals who brought in prisoners listed in an eighth-century Greek papyrus, agents of a large estate (oikos) and two privately appointed policemen appear besides government officials. ${ }^{154}$ Prisons continued to exist on estates into the first half of the seventh century. ${ }^{155}$ Bishops sat in judgement on thieves and other offenders, sending them to prisons, which they controlled, although it is not clear how far their jurisdiction extended beyond their domains. ${ }^{156}$ Village headmen, bishops and 'private' individuals are addressed in seventh-century texts concerning prisoners, indicating that they had jurisdiction, or at least some kind of influence, over the places where the prisoners were held. ${ }^{157}$

Some fifty years after the conquest, in around 70o, as the caliphate expanded its political and cultural ambitions, a fundamental re-arrangement of the Egyptian countryside was undertaken. Arab-Muslims started to replace Egyptians as the pagarchs or heads of local districts. ${ }^{158}$ As Muslims increasingly settled

151 Petra M. Sijpesteijn, "Loyal and Knowledgeable Supporters: Integrating Egyptian Élites in Early Islamic Egypt," (forthcoming).

$15^{2}$ See also Menas who is called stratiōtēs and is involved with the Arab authorities, but it is not clear what his function was exactly (P.Lond. v 1738; 1743; 1744; 1748; 1749; 1751; 1864, dating to $649^{-75}$, provenance of all is al-Ashmūnayn. For the date, see Jean Gascou, "Reçu d' impôt pour le Prince des Croyants," in Inediti offerti a Rosario Pintaudiper il suo $65^{\circ} \mathrm{com}$ pleanno (P.Pintaudi), ed. Diletta Minutoli (Firenze: Edizioni Gonnelli, 2012), 132).

153 P.Mon.Epiph. 167, seventh century, provenance Jēme.

$154 S P P \times 252$, provenance al-Fayyūm.

155 Despite laws banning private prisons as well as the use of private soldiers (Torallas Tovar, "Violence," 109-110; Robinson, "Private Prisons"). For examples of prisons belonging to large estates, see P.Oxy XXVII 2478, dating to 595; P.Oxy LXX 4802, dating to 6oo-625; P.Oxy XxIV 2440, dating to 614; P.Oxy XVI 2056, seventh century; $S B$ XVIII 14006, dating to 635 , provenance of all is Oxyrhynchus.

${ }_{15} 6$ For stealing from the bishop's granaries, see P.Berl.Zill. 8, dating to 663, provenance alFayyūm. A bishop's prison is mentioned in $S B$ I 4658 , dating to $670-68$ o, provenance al-Fayyūm. Both are cited by Foss, "Mu'āwiya," 266, 267, n. 40.

157 See below nn. 183-185.

$15^{8}$ Sijpesteijn, "Arab Conquest;" idem, Shaping a Muslim State, 112-114. 
outside the garrison cities, processes of Arabicisation and Islamicisation were accelerated. Concurrently, Islamic institutions and theories developed in the urban centres of learning and rule found their way into the hinterland. Islamic law developed as a text-based system of thought and hermeneutics within the framework of a public, court-based infrastructure. ${ }^{159}$

The expansion and formalisation of state and, later, legal infrastructures reduced the degree to which criminal law cases could be dealt with outside official channels. While members of the local élite continued to be asked to solve conflicts internal to the community, especially through mediation, the power to impose punishment and incarceration shifted to the political-administrative realm, now manned by Arab-Muslims. ${ }^{160}$ Initiatives introduced by the political centre coincided with choices initiated from the bottom up as power was redistributed, creating altered constellations of control and giving room to new players.

From the eighth century Arab-Muslim state representatives - governors, pagarchs, village headmen and other officials at the village level - are increasingly involved in the application of criminal justice. The Arab-Muslim officials who took over from Egyptians as heads of the pagarchies had greater administrative and legal responsibilities. They were bureaucrats, whose ties to the political administration were stronger than to the land they ruled. This is reflected in their title, which emphasises the holder's connection to the government (Ar.'ämil al-amìr 'alā followed by a place name) rather than exclusively to his locality, in contrast to his Christian provincial predecessors (șạhib combined with a place name). ${ }^{161}$

An increased appropriation of the justice system by the Arab-Muslim administration is also visible at the village level. Those involved in the tracking down and punishment of law-breakers now carried official titles and/or operated in a governmental context. They were also often sent down from administrative centres to deal with local problems or track down tresspassers. See for example the eighth-century Arabic papyrus in which an official reports, presumably to the central office that had dispatched him, from a village in UpperEgypt that he had stopped the rebellion and re-installed the tax-collector. ${ }^{162} \mathrm{~A}$

\footnotetext{
159 See for this general development in the Egyptian context, Ahmed El Shamsy, The Canonization of Islamic Law: A Social and Intellectual History (Cambridge: Cambridge University Press, 2013); Tillier, "Pagarque."

16o Petra M. Sijpesteijn, "Establishing Local Élite Authority in Egypt Through Arbitration and Mediation," in Regional and Transregional Elites: Connecting the Early Islamic Empire, eds. Stefan Heidemann and Hannah-Lena Hagemann, Studies in the History and Culture of the Middle East (Berlin, forthcoming).

161 Sijpesteijn, Shaping a Muslim State, 103.

162 P.Cair.Arab. vi. Unpublished.
} 
ninth-century order to have a female brought forward contains a seal with the name al-Hasan, similarly suggesting an administrative context. ${ }^{163}$ Nevertheless, into the ninth century the locally situated village headmen continued to play a role in the maintenance of order in the village. In an eighth-century letter the sender reports that the village headman $(w \bar{a} l \bar{\imath})$ fined and arrested him. ${ }^{164}$ In the ninth century a wāli al-qarya received instructions to suppress criminals and suspects (Ar. ahl al-jaräim wa-l-rïb) he finds in the area under his control, to punish anyone who oppresses the villagers, and to inform all guards (Ar. hurrās), aides (Ar. a'wān) and workers on the estate (Ar. ahl al-day'a) of these instructions. ${ }^{165}$ Also in the ninth century, a certain Abu Furāt, the responsible person (Ar. wakīl) in Babīj, a town in the Fayyūm, receives a request to examine a conflict between two individuals. ${ }^{166}$

The transfer of carceral processes to the public sphere might very well have been part of these developments. ${ }^{167}$ Prisons became increasingly publicly managed and seem to become dominated by purposely and formerly organised structures. ${ }^{168}$ An eighth-century Greek list of prisoners from the Fayyūm cited above is headed by a reference to the prison where the detainees were held. "Register of the prison in the village of Pitoul" it says at the top of the list. 169 More information about the superintendent responsible for the prison is given in another list of imprisoned fugitives from the Fayyüm. It is dated between $75^{\circ}$ and 769 and gives the names of men and women, the latter probably imprisoned in place of their runaway husbands, "thrown in the prison of the amir 'Abd Allāh b. 'Abd al-Raḥmān."170 While 'Abd Allāh b. 'Abd al-Raḥmān's function is not explicitly mentioned, his title of amir places him firmly in the Arab-Muslim administration and he most probably stood at the head of a local district. Other

\footnotetext{
163 PERF 699, provenance not mentioned.

164 P.Khalili I 14, provenance not mentioned.

165 P.Ryl.Arab. I I 17, provenance not mentioned.

166 Chrest.Khoury i 84.

167 A similar transformation from private to public is observed in early (conquest) Arabia by Anthony ("Domestic Origins," 574). This change which occurred in Arabia in the middle of the seventh century was thus not comprehensive and definite. Rather, similar kinds of concerns and dynamics that motivated the adoption of formal prison structures over private incarceration practices in early Muslim Arabia played a role in early eighth-century Egypt.

168 See also the prison built as a prison in Fusțāt by 'Īsā b. Yazīd who arrived in Egypt in the early ninth century with 'Abd Allāh b. Țāhir's armies (Ibn 'Abd al-Hakam (d. 257/871), Kitāb futūh mișr wa-akbārihā, ed. Charles Torrey as: The History of the Conquests of Egypt, North Africa, and Spain (New Haven: Yale University Press, 1922), 112).

169 P.Horak. 64, provenance al-Fayyūm.

$170 \quad C P R$ XXII 35, provenance al-Fayyūm.
} 
Greek papyri show that 'Abd Allāh indeed performed official duties related to tax collection. ${ }^{171} \mathrm{He}$ might, moreover, be the same as the 'Abd Allāh b. 'Abd al-Rahmān who appears in the mid-eighth century as the āmil of alAshmūnayn. ${ }^{172}$ In the 73 os, 'Abd Allāh b. As'ad, responsible for the tax collection and administrative management of the southern Fayyüm, was also in charge of a prison. ${ }^{173}$

The increased involvement of Arab officials in the penal system is also evident from the standardised procedures that appear in the documentation, as well as the formulaic expressions that are used. Government officials generally required a certain amount of evidence. Already from the second half of the seventh century, "evidence" (Ar. bayyina) is demanded by the administrators to corroborate a claim. ${ }^{174}$ Later examples are more extensive, with demands for "sound evidence and clear proof" (Ar. al-bayyina al-ādila wa-l-burhān almubayyin). ${ }^{175}$ The documents attest a consistent procedure to have been in place, with fact-finding missions assigned to lower layers in the administrative hierarchy and usually conducted by questioning the accused party, and the resulting reports travelling back up the administrative ladder. As discussed above, from the eighth century, the papyri also show a standardised technical vocabulary and idiomatic expressions for dealing with legal conflicts and offences.

The increased presence of a well-developed public legal system is also evident in the efforts that were made to handle certain cases outside the system or at least in an informal manner. Dealing privately with an offender allowed the case to be handled less officially. This is clear, for example, from the letter in which the sender asks that a manumitted slave accused of theft be beaten to confess his crime and return the items he has stolen. ${ }^{176}$ In another case of theft on an estate, the owner and victim of the crime also attempts to keep the case outside the jurisdiction of the authorities. ${ }^{177}$ These cases of theft might have been considered to belong to the private domain and therefore to be dealt with outside the official system. Similarly, it has been argued that the popularity of

171 Nikolaos Gonis, "Another Look at Some Officials in Early 'Abbāsid Egypt," Zeitschrift für Papyrologie und Epigraphik 149 (2004): 194-195.

172 Marie Legendre, "La Moyenne-Égypte du vire au IXe siécle: apports d'une perspective régionale à l'étude d' une société entre Byzance et l' Islam" (PhD diss., Paris-Sorbonne University, 2014), 436.

173 Sijpesteijn, Shaping a Muslim State, no. 19, ca. 730, provenance al-Fayyūm.

174 Diem, "Gouverneur." For the significance of the use of bayyina, see Tillier, "Dispensing Justice," 143-145.

175 P.Ryl.Arab. I ViI 6, ninth century, provenance not mentioned.

176 Chrest.Khoury i 84, ninth century, provenance probably al-Fayyūm.

177 P.World, p. 186, dating $170 / 786-787$, provenance unknown. 
mediation in Abbasid Iraq was motivated by the fact that it offered a quicker solution to a conflict than going through the lengthy and costly court proceedings. ${ }^{178}$

The same might have applied to hostage-taking in the case of non-payment of debts, which often seems still to have occurred in a private context. The accounts in the literary sources of makeshift holding places to detain debtors for a limited period seem to be related to this practice. ${ }^{179}$ Even in the ninthcentury papyri there are suggestions that private incarceration practices continued supplemental to public prisons. Individuals are described as being "in his hands" (Ar. fi yadayhi), often in combination with a general remark of being kept or imprisoned ( $h-b-s)$, suggesting a more private situation, with confinement being associated with an individual in charge, rather than a public institution. ${ }^{180}$ Other documents contain indications that people were sometimes captured by private individuals, such as the eighth-ninth-century letter in which the guard of the sender was confined by the addressee (Ar. qad habasta rasūlī ${ }^{181}$

An informal approach can also be observed in letters requesting the freeing of prisoners. Prison supervisors and other local authorities seem to have had the power to release prisoners. ${ }^{182}$ This applies both to 'public' prisons run by village headmen, pagarchs and other representatives of the state authorities, and 'private' prisons. Numerous petitions written by or on behalf of prisoners were directed at those in charge of the prison or at individuals deemed to have some influence over the fate of the prisoners. In a seventh-century Coptic letter a group of inhabitants from Jēme asks the abbot of the monastery of Epiphanius to write a letter to the village headman (Cop. lashane), who seems to have possessed certain administrative powers, to free some inhabitants from the same town held in three different places. ${ }^{183}$ In a Coptic ostracon, the writer asks the (unspecified) addressee to free a prisoner who is needed in "the season of work." ${ }^{184}$ In another seventh-century Coptic ostracon the sender pleads that

178 Mathieu Tillier, "Le temps de la justice aux premiers siècles de l' Islam," Revue des Mondes Musulmans et de la Méditerranée 136 (2014): 71-88.

179 Anthony, "Domestic Origins;" Schneider, "Imprisonment," 16o.

180 Cf. wa-hum maḥbūsina ilä an katabtu ilayka wa-hum fi-yadayhi bi-l-madìna (CPR XVI 11, ninth century, provenance not mentioned).

181 P.Prag.Arab. 53, provenance unknown.

182 Cf. Tillier, "Prisons et autorités urbaines," $392 \mathrm{ff}$.

183 P.Mon.Epiph. 163. Cf. P.Mon.Epiph. 178, seventh century, provenance Jēme.

184 Crum, Coptic Ostraca, no. Ad 27, provenance and date unknown. For other examples of prisoners being prevented from undertaking their agricultural obligations, see above nn. $112-116$. 
since the addressee once asked the sender to release one of his prisoners on the former's behalf, he should now do the same for the sender. ${ }^{185}$ In a seventhcentury Greek letter the pagarch Flavius Theodorakios is asked to release a prisoner. ${ }^{186}$ See also the requests cited above to release workers committed to fulfil corvée labour locally or a the capital directed to local administrators and pagarchs. ${ }^{187}$

The way in which (legal) conflicts were settled and offences dealt with by state officials and other authorities in the Egyptian countryside shows how power relations between the different population groups shifted after the conquest. Initially Byzantine practice prevailed: an indigenous 'middle élite' at the village level, associated to the religious infrastructure and/or based on economic hegemony, overlapped with administrative functionaries in the maintenance of order, the application of criminal law, and the resolution of legal conflicts. Changes in the administrative composition affected the disciplinary space in which local élites were able to operate and the capacity in which they did so. An expanding and increasingly professionalised Muslim (legal) administration gradually dominated the Egyptian countryside. Indigenous Christian and Jewish middle élites continued to be hugely important power brokers between the ruling authorities and the local population. As a result their role in the handling of conflicts remained equally significant. Increasingly, however, a growing Muslim administrative and legal infrastructure in the countryside dealt with cases of penal law and instances of public order. Similarly, mediation and requests for help, which initially fell in the domain of local Egyptians, were more and more dealt with by and directed to Arab-Muslims as they took the place of EgyptianChristians and Jews, first in the administrative and then in the socio-economic hierarchy of the countryside. ${ }^{188}$

Non-Muslim Egyptians progressively turned to the Muslim legal authorities because they saw them as having more decision-making power in the settling of conflicts. ${ }^{189}$ Qādī Khayr b. Nu'aym (in office 739-745) used to adjudicate in Fus-

\footnotetext{
185 P.Mon.Epiph. 167, seventh century, provenance Jēme.

186 CPR XXIV 32, dating to 651, provenance Madīnat al-Fayyūm.

187 See above, nn. $112-117$.

188 This argument will be expanded on in a forthcoming publication of mine: Sijpesteijn, "Establishing Local Élite Authority."

189 Morony, "Religious Communities;" Mikhail, From Byzantine to Islamic Egypt, $157 \mathrm{ff}$.
} 
țāt between Christians after he had finished dealing with the Muslim cases.190 On the other hand, as Uri Simonsohn has shown, the Muslim courts could also be used to undermine the authority of community leaders in a political power game. ${ }^{191}$ In other cases, however, the parties involved in legal cases and conflicts explicitly tried to keep out the Muslim authorities.

The growth of the role of Muslim legal institutions in the Egyptian countryside especially in the domain of criminal law was the result of three related processes. Standardisation in the Islamic legal domain led to a more extensive and better defined role for Islamic judges vis-à-vis representatives of the political power, without denying the latter a role in the application of criminal law. Administrative reforms aimed at increased Islamicisation and Arabicisation resulted in a greater presence of the Arab administration. Arab-Muslim officials replaced Egyptian-Christians at the lower administrative levels and acquired greater executive and legal powers in the process. The result was a decentralisation of functions from the capital to the provincial towns, where Muslim-Arab administrators obtained greater authority vis-à-vis indigenous élite members. The resulting loss of social standing amongst Egyptian Christians further eroded their status as arbiters and dispensers of the law.

While mediation and arbitration continued to be an important vehicle for solving legal disputes, the public legal system had grown with other state structures to the point that it became increasingly difficult to keep issues out of the public officers' domain, even if these occurred within the jurisdiction of the parties involved. It was no longer self-evident that cases could be dealt with outside the official legal channels, as the owner of an estate implicitly acknowledges when he begs the addressee of his letter to allow him to deal with a theft of 70 bushes of straw on his property himself rather than bringing the case to the attention of the Muslim-Arab authorities: ${ }^{192}$ the owner had to convince the authorities to allow him to keep matters in his own hands. Criminal justice and especially the ability to assign punishments had become largely the monopoly of the Muslim state. Within their own domains, local authorities continued to play a role both in ecclesiastical and rabbinical courts and as mediators with higher (Muslim) authorities. ${ }^{193}$ By the tenth-eleventh century,

\footnotetext{
190 al-Kindī, Kitāb al-quḍāt, 351.

191 Eighth-century canons contain harsh punishments for those calling for intervention in church affairs by Muslim and other non-ecclesiastical authorities (Simonsohn, "Blessed," 101).

192 Jahn, "Briefwesen," no. 17, eighth-ninth century, provenance unknown.

193 The role of local authorities as mediators might in fact to have grown exactly at times when their public role diminished (Sijpesteijn, "Establishing Local Élite Authority").
} 
however, a bishop could only threaten a thief with curses if he did not return the goods he had stolen. ${ }^{194}$ This stood in stark contrast to his seventh-century predecessor who could send a thief to the bishop's own prison.

The tools to police and impose punishments at the disposal of the ArabMuslim authorities in the Egyptian countryside did not differ much from those in place in the late Roman period. Prisons functioned mainly to hold those suspected, accused or convicted of crimes until such time as they were sentenced and released, or had fulfilled their punishment, or as a compulsory measure for the recovery of debts, either from the prisoner him- or herself or a third party. With prisons seemingly not purpose-built, and hence less secure, incarceration often required extra measures, such as guarantees, especially in the cases of those likely to run away. Punishments were overwhelmingly applied in the form of monetary fines, which in the case of non-payment could result in being gaoled. Conversely, non-payments of debts, fines and taxes was the main reason for imprisonment, and imprisonment lasted until the payment had been made. Using family members or other dependents as proxies, even to the extent of imprisoning them, seems to have been a common way to pressure culprits. New punishments were also introduced by the Arabs, with the physical punishments such as flogging or imprisonment of runaway peasants and corrupt tax collectors, or the cutting of hair and beards, being the most remarkable.

The history of control of public order and conflict resolution in the early Islamic Egyptian countryside is shaped by the same intertwined processes that drove the development of a Muslim state in Egypt. Cultural penetration through Arabicisation and Islamicisation made Muslim legal and administrative institutions increasingly accessible and prestigious to indigenous Egyptians. In their turn Egyptians progressively re-shaped the governmental framework in the course of their interaction with it. The development of governmental institutions, with a theoretical and intellectual system to support them, and the related standardisation and professionalisation of practice led to clearer boundaries between public and private, with the appropriation of the public order and penal law by the Islamic authorities. Differentiation was never absolute, of course, and overlap continued to exist with participants adjusting their strategies of interaction and engagement as contexts evolved. Finally, the conquest and the political-administrative decisions that followed from it resulted in new social groupings, new kinds of relationships between them, and new power structures.

194 Walter Crum, Catalogue of the Coptic Manuscripts in the Collection of the John Rylands Library (Manchester: Manchester University Press, 1909), no. 267, provenance al-Ashmūn. Discussed by Mikhail, From Byzantine to Islamic Egypt, 156. 


\section{Bibliography}

\section{Primary Sources}

Ibn 'Abd al-Hakam (d. 257/871). Kitāb futūḥ mișr wa akbārahā. Edited by Charles Torrey as: The History of the Conquests of Egypt, North Africa, and Spain. New Haven: Yale University Press, 1922.

al-Kindī, Muḥammad b. Yūsuf. Kitāb al-wulāt wa kitāb al-quḍāt. Edited by Rhuvon Guest as: The Governors and Judges of Egypt. Leiden: Brill, 1912.

al-Maqrīzī (d. 845/1442). al-Mawā'iz wa-l-itibār fı̀ dhikr al-khițaț wa-l-āthār. Edited by Ayman F. Sayyid. London: al-Furqan Islamic Heritage Foundation, 2002-2003.

\section{Secondary Sources}

Anthony, Sean W. "The Domestic Origins of Imprisonment: An Inquiry Into an Early Islamic Institution." Journal of the American Oriental Society 129 (2009): 571-596.

Anthony, Sean W. Crucifixion and Death as Spectacle: Umayyad Crucifixion in Its Late Antique Context. New Haven, ст: American Oriental Society, 2014.

Becker, Carl. H. “Arabische Papyri des Aphroditofundes.” Der Islam 2 (1911): 245-268.

Boud'hors, Anne, and Chantal Heurtel. Les ostraca coptes de la TT29: autour du moine Frangé. Études de l' archéologie thébaine 3. Brussels: CReA-patrimoine, 2010.

Bruning, Jelle. "A Legal Sunna in Dhikr Haqqs From Sufyanid Egypt." Islamic Law and Society 22 (2015): 1-23.

Crum, Walter. Coptic Ostraca from the Collections of the Egypt Exploration Fund, the Cairo Museum and Others. London: The Egyptian Exploration Fund, 1902.

Crum, Walter. Catalogue of the Coptic Manuscripts in the Collection of the John Rylands Library. Manchester: Manchester University Press, 1909.

David-Weill, Jean, et al. "Papyrus arabes du Louvre III." Journal of the Economic and Social History of the Orient 21 (1978): 146-164.

Diem, Werner. "Der Gouverneur an den Pagarchen: ein verkannter Papyrus vom Jahre 65 der Hiğra." Der Islam 6o (1983): 104-111.

Diem, Werner. "Vier Dienstschreiben an 'Ammār." Zeitschrift der Deutschen Morgenländischen Gesellschaft 133 (1983): 239-262.

Diem, Werner. "Drei amtliche Schreiben aus frühislamischer Zeit (Papyrus Erzherzog Rainer, Wien)." Jerusalem Studies in Arabic and Islam 12 (1989): 146-165.

Diem, Werner. "Philologisches zu arabischen Dokumenten, II: Dokumente aus der Sammlung der Egyptian Library in Kairo." Zeitschrift für Arabische Linguistik $5^{6}$ (2012): 27-78.

Dietrich, Albert. Arabische Briefe aus der Papyrussammlung der Hamburger Staats- und Universitäts-Bibliothek. Hamburg: J.J. Augustin, 1955.

El Shamsy, Ahmed. The Canonization of Islamic Law: A Social and Intellectual History. Cambridge: Cambridge University Press, 2013. 
Foss, Clive. "Egypt under Mu'āwiya, part I: Flavius Papas and Upper Egypt." Bulletin of the School for Oriental and African Studies 72 (2009): 1-24.

Gascou, Jean. “Les grands domaines, la cité et l'État en Égypte Byzantine." Travaux et Mémoires 9 (1985): 1-9o.

Gascou, Jean. "Trois orders de liberation d'époque arabe." In Papyrin Mememory of P.J. Sijpesteijn, edited by A.J. Boudewijn Sirks and Klaas A. Worp, 161-167. American Studies in Papyrology 40. Chippenham: The American Society of Papyrologists, 2007.

Gascou, Jean. "Reçu d'impôt pour le Prince des Croyants." In Inediti offerti a Rosario Pintaudi per il suo $65^{\circ}$ compleanno (P.Pintaudi), edited by Diletta Minutoli, 132-134. Firenze: Edizioni Gonnelli, 2012.

Gascou, Jean, and Klaas A. Worp. "Problèmes de documentation apollinopolite." Zeitschrift für Papyrologie und Epigraphik 49 (1982): 83-95.

Geltner, Guy. The Medieval Prison: A Social History. Princeton: Princeton University Press, 2008.

Gonis, Nikolaos. "Another Look at Some Officials in Early 'Abbāsid Egypt." Zeitschrift für Papyrologie und Epigraphik 149 (2004): 189-195.

Gould, Rebecca. "Prisons before Modernity: Incarceration in the Medieval IndoMediterranean." al-Masāq: Islam and the Medieval Mediterranean 24 (2012): 179-197.

Grohmann, Adolf. "Der Beamtenstab der arabischen Finanzverwaltung in Ägypten in früharabischer Zeit.” In Studien zur Papyrologie und antiken Wirtschaftsgeschichte: Friedrich Oertel zum achtzigsten Geburtstag gewidmet, edited by Horst Braunert, 120-134. Bonn: R. Habelt, 1964.

Hanafi, Alia. "An Arabic Will Written on a Ship." In Proceedings of the Twenty-Fifth International Congress of Papyrology, Ann Arbor 2007, edited by Traianos Gagos, 299-306. American Studies in Papyrology. (Ann Arbor: University of Michigan Press, 2010).

Harrauer, Hermann. "Matrazen für Gefangene." Archiv für Papyrusforschung 33 (1987): 69-72.

Hentati, Nejmeddine. "La prison en Occident musulman médiéval." Arabica 54 (2007): 149-188.

Jahn, Karl. “Vom frühislamischen Briefwesen." Archiv Orientální 9 (1937): 153-200.

Keenan, James G., Joe G. Manning and Uri Yiftach-Firanko, eds. Law and Legal Practice in Egypt from Alexander to the Arab Conquest. Cambridge: Cambridge University Press, 2014.

Khan, Geoffrey. Bills, Letters and Deeds: Arabic Papyri of the seventh to eleventh Centuries. Oxford: Khalili Collections, 1993.

Krall, Jakob. "Neue koptische und griechische Papyrus." Recueil de travaux relatifs à la philologie et à l'archéologie égyptiennes et assyriennes 6 (1885): 63-79.

Krause, Jens-Uwe. Gefängnisse im römischen Reich. Stuttgart: Steiner, 1996.

Legendre, Marie. "La Moyenne-Égypte du vire au Ixe siécle: apports d'une perspective 
régionale à l' étude d' une société entre Byzance et l' Islam." PhD diss., Paris-Sorbonne University, 2014.

Legendre, Marie. "Neither Byzantine nor Islamic? The Duke of the Thebaid and the Formation of the Umayyad State." Historical Research 89 (2016):3-18.

MacCoull, Leslie. "The Coptic Papyri from Apollonos Ano." In Proceedings of the XVIIIth International Congress of Papyrology, edited by Basil G. Mandilaras, 141-16o. Athens: Greek Papyrological Society, 1988.

MacCoull, Leslie. Coptic LegalDocuments: Law as Vernacular Text and Experience in Late Antique Egypt. Tempe: Arizona Center for Medieval and Renaissance Studies, 2009. Mikhail, Maged S.A. From Byzantine to Islamic Egypt. London/New York: I.B. Tauris, 2014.

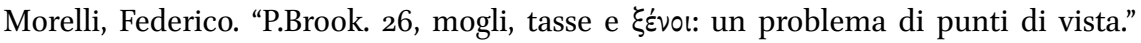
Zeitschrift für Papyrologie und Epigraphik 130 (2000): 218-222.

Morony, Michael. "Religious Communities in the Early Islamic World." In Visions of Community in the Post-Roman World: The West, Byzantium and the Islamic World, 300-1100, eds. Walter Pohl, Clemens Gantner and Richard Payne, 155-163. London: Routledge, 2012.

Palme, Bernhard. "The Imperial Presence: Government and Army." In Egypt in the Byzantine World 300-700, edited by Roger S. Bagnall, 244-270. Cambridge: Cambridge University Press, 2007.

Peters, Rudolph. Crime and Punishment in Islamic Law: Theory and Practice from the Sixteenth to the Twenty-First Century. Themes in Islamic Law 2. Cambridge: Cambridge University Press, 2005.

Rāg̀ib, Yūsuf. "Lettres Arabes (I)." Annales Islamologiques 14 (1978): 15-35.

Reinfandt, Lucian. "Crime and Punishment in Early Islamic Egypt (642-969)." In Proceedings of the Twenty-Fifth International Congress of Papyrology, Ann Arbor 2007, edited by Traianos Gagos, 633-640. American Studies in Papyrology. Ann Arbor: University of Michigan Press, 2010.

Reinfandt, Lucian. "Law and Order in der frühen islamischen Gesellschaft? Strafverfolgung in Ägypten und Palästina nach der arabischen Eroberung (7.-9. Jahrhundert).” In Interkulturalität in der Alten Welt: Vorderasien, Hellas, Ägypten und die vielfältigen Ebenen des Kontakts, eds. Robert Rollinger, et al., 655-682. Wiesbaden: Harrassowitz Verlag, 2010.

Reinfandt, Lucian. "Local Judicial Authorities in Umayyad Egypt (41-132/661-750)." Bulletin d'études orientales 63 (2014): 127-146.

Richter, Tonio Sebastian. "Language Choice in the Qurra Dossier." In The Multilingual Experience in Egypt, from the Ptolemies to the Abbāsids, edited by Arietta Papaconstantinou, 189-220. Burlington: Ashgate Publishing, 2010.

Robinson, Olivia. "Private Prisons." Revue international des droits de l'antiquité 15 (1969): 389-398. 
Rosenthal, Frantz. The Muslim Concept of Freedom. Leiden: Brill, 196o.

Schneider, Irene. "Imprisonment in Pre-Classical and Classical Islamic Law." Islamic Law and Society 2 (1995): 157-173.

Schneider, Irene. “Sidjn," In Encyclopaedia of Islam, 2nd edition, vol. 9. Edited by P. Bearman, Th. Bianquis, C.E. Bosworth, E. van Donzel and W.P. Heinrichs, 547-548. Leiden: Brill, 1997.

Schneider, Irene. Kinderverkauf und Schuldknechtschaft: Untersuchungen zur frühen Phase des islamischen Rechts. Abhandlungen für die Kunde des Morgenlandes vol. 52, no. 1. Stuttgart: Kommissionsverlag Franz Steiner, 1999.

Schneider, Irene. "Freedom and Slavery in Early Islamic Time (first/seventh and second/eighth Centuries)." al-Qantara 28 (2007): 353-382.

Sijpesteijn, Petra M. “The Arab Conquest of Egypt and the Beginning of Muslim Rule.” In Egypt in the Byzantine World 300-70o, edited by Roger S. Bagnall, 437-459. Cambridge: Cambridge University Press, 2007.

Sijpesteijn, Petra M. “Une nouvelle lettre de Qurra b. Šarīk. P.Sorb. inv. 2345." Annales Islamologiques 45 (2011): 257-267.

Sijpesteijn, Petra M. Shaping a Muslim State: The World of a Mid-Eighth-Century Egyptian Official. Oxford: Oxford University Press, 2013.

Sijpesteijn, Petra M. “Financial Troubles: A Mamluk Petition." In Jews, Christians and Muslims in Medieval and Early Modern Times: A Festschrift in Honor of Mark R. Cohen, eds. Arnold E. Franklin, Roxani E. Margariti, Marina Rustow and Uriel Simonsohn, 352-366. Leiden: Brill, 2014.

Sijpesteijn, Petra M. "Delegation of Judicial Power in Abbasid Egypt." In Legal Documents as Sources for the History of Muslim Societies: Studies in Honour of Rudolph Peters, eds. Maaike van Berkel, Léon Buskens and Petra M. Sijpesteijn, 61-84. Leiden: Brill, 2017.

Sijpesteijn, Petra M. "Shaving Hair and Beards in Early Islamic Egypt: Muslim Innovation or Universal Punishment?" al-Masāq:Journal of the Medieval Mediterranean 30, no. 1 (2018): 9-25.

Sijpesteijn, Petra M. "Establishing Local Élite Authority in Egypt Through Arbitration and Mediation." In Regional and Transregional Elites: Connecting the Early Islamic Empire, eds. Stefan Heidemann and Hahhag-Lena Hagemann. Studies in the History and Culture of the Middle East. (Berlin, forthcoming).

Sijpesteijn, Petra M. "Loyal and knowledgeable Supporters: Integrating Egyptian Élites in Early Islamic Egypt." (forthcoming)

Silverstein, Adam. Postal Systems in the Pre-Modern Islamic Worlds. Cambridge: Cambridge University Press, 2007.

Simonsohn, Uri. A Common Justice: The Legal Allegiances of Christians and Jews Under Early Islam. Philadelphia: University of Pennsylvania Press, 2011.

Simonsohn, Uri. "Blessed are the Peace Makers: An Ecclesiastical Definition of Author- 
ity in the Early Islamic Period." In Mediations on Authority, edited by David Shulman, 101-127. Martin Buber Society of Fellows Notebook Series. Jerusalem: Magnes Press, 2013.

Tillier, Matthieu. Vies des cadis de Mișr 237/851-366/976. Cahier des Annales Islamologiques 24. Cairo: Institut Français d'Archéologie Orientale, 2002.

Tillier, Mathieu. "Prisons et autorités urbaines sous les Abbassides." Arabica 55 (2008): 387-408.

Tillier, Mathieu. "Vivre en prison à l'époque Abbasside." Journal of the Economic and Social History of the Orient $5^{2}$ (2009): 635-659.

Tillier, Mathieu. "Les prisonniers dans la société musulman (IIe/virie-Ive/Xe)." In Dynamiques sociales au Moyen Âge en Occident et en Orient, edited by Elisabeth Malamut, 191-212. Aix-en-Provence: Publications de l'Université de Provence, 2010.

Tillier, Mathieu. Histoire des cadis égyptiens (Aḩbār quḍāt Mișr). Cairo: Institut français d' archéologie orientale, 2012.

Tillier, Mathieu. "Du pagarque au cadi: Ruptures et continuités dans l' administration judiciaire de la haute-Égypte (Ier-IIIe/vire-IXe siècle)." Médiévales 64 (2013): 19-36.

Tillier, Mathieu. "Deux papyrus judiciaires de Fusțāt ( $\mathrm{II}^{\mathrm{e}} / \mathrm{VIII}^{\mathrm{e}}$ siècle)." Chronique d'Egypte 89 (2014): 412-445.

Tillier, Mathieu. "Le temps de la justice aux premiers siècles de l' Islam." Revue des Mondes Musulmans et de la Méditerranée 136 (2014): 71-88.

Tillier, Mathieu. "Dispensing Justice in a Minority Context: The Judicial Administration of Upper Egypt under Muslim Rule in the Early Eighth Century." In The Late Antique World of Early Islam: Muslims among Jews and Christians in the East Mediterranean, edited by Robert Hoyland, 133-156. Princeton: Darwin Press, 2015.

Torallas Tovar, Sofía. "Violence in the Process of Arrest and Imprisonment in Late Antique Egypt." In Violence in Late Antiquity: Perceptions and Practices, edited by H. Drake, 101-110. London: Ashgate, 2006.

Vantieghem, Naim. "La correspondance de Qurra b. Šarīk et de Basileios revisitée. I. À propos d' une lettre récemment publiée." Chronique d'Egypte 91 (2016): 204-210.

Wilfong, Terry G. Women of Jeme: Lives in a Coptic Town in Late Antique Egypt. Ann Arbor: University of Michigan Press, 2002. 